Inceleme Makalesi - Review Article

\title{
Ayrımcılık Temelli Dışlanma: Türkiye'de Çalışma Hayatında Kadınlar
}

\section{Exclusion Based on Discrimination: Women at Work in Turkey}

\author{
Sinem YILDIRIMALP* \\ (iD) 0000-0003-0171-5916
}

Sosyal Güvenlik Dergisi / Journal of Social Security

Cilt: 11 Say1: 2 Y1l: 2021 /Volume: 11 Issue: 2 Year: 2021

Sayfa Aralığı: 321-346 / Pages: 321-346

DOI: $10.32331 /$ sgd.1049046

\section{ÖZ}

Ayrımcılık, bireye ya da gruba sahip olduğu özellikler sebebiyle eşit davranmamak, özensiz davranmak olarak tanımlanmaktadır. Ayrımcı davranışlar sosyal ve ekonomik yaşamda eşitsizliklere ve dışlanmaya sebep olmaktadır. Kadınlar, ayrımcılığa maruz kalan grupların başında gelmektedir. Cinsiyete dayalı ayrımcılık, kadınların firsat ve işlem eşitsizlikleri yaşamasına ve özellikle çalışma yaşamından dışlanmalarına neden olmaktadır. Bu çalışmada, betimsel analiz yöntemi kullanılarak Türkiye'de kadınların ayrımcılık sebebiyle çalışma hayatından dışlanma sorunu ele alınmakta ve işgücü istatistikleri üzerinden analizi yapılmaktadır. $\mathrm{Bu}$ doğrultuda Türkiye'de kadınların çalışma hayatına girişte ve çalışma yaşamı içerisinde erkeklere göre dezavantajlı oldukları, toplumsal cinsiyete dayalı ayrımcılık ve bu ayrımcılığın kaynaklık ettiği eşitsizlikler yaşadıkları sonucuna ulaşılmaktadır. İşgücüne katılım ve istihdam oranlarında erkeklerin gerisinde kalan kadınların, kayıt dışı çalışma ve işsizlik oranlarında erkeklerden önde olduğu görülmektedir. Kadınlar, erkeklerden daha az ücret elde etmekte, yönetim kademelerinde daha az yer almakta ve sendikal örgütlenmede yine erkeklerin gerisinde kalmaktadır.

Anahtar Sözcükler: Ayrımcılık, eşitsizlik, dişlanma, çalışma hayatı

\section{ABSTRACT}

Discrimination is defined as not treating an individual or group unequally because of their characteristics and behaving carelessly. Discriminatory behaviors cause inequalities and exclusion in social and economic life. Women are at the forefront of the groups exposed to discrimination. Gender-based discrimination causes women to experience inequality of opportunities and procedures and be excluded from working life. In this study, the exclusion of women from working life due to discrimination in Turkey is handled using the descriptive analysis method and analyzed through labor force statistics. In this direction, it is concluded that women in Turkey are at a disadvantage compared to men in entering and working life, and they experience discrimination based on gender and inequalities caused by this discrimination. It is observed that women, who lag behind men in labor force participation and employment rates, are ahead of men in unregistered work and unemployment rates. Women earn fewer wages than men, take fewer management positions, and still lag behind men in union organizations.

Keywords: Discrimination, inequality, exclusion working life

Önerilen atıf şekli: Yıldırımalp, S. (2021). Ayrımcılık Temelli Dışlanma: Türkiye'de Çalışma Hayatında Kadınlar. Sosyal Güvenlik Dergisi (Journal of Social Security). 11(2). 321-346.

- Geliş Tarihi/Received: 31/05/2021 • Güncelleme Tarihi/Revised: 15/11/2021 • Kabul Tarihi/Accepted: 27/12/2021

Doç. Dr., Sakarya Üniversitesi, Siyasal Bilgiler Fakültesi, Çalışma Ekonomisi ve Endüstri İlişkileri Bölümü, ssac@sakarya.edu.tr 


\section{GíRIŞ}

Önyargılı, eşitsiz ve haksız muameleyi kapsayan ayrımcılık, sosyal politikanın ilgilendiği önemli bir sosyal sorundur. Belli grupların doğuştan ya da sonradan edinilen özellikleri sebebiyle ayrımcılığa maruz kalarak dezavantajlı duruma gelmesi sürecini ifade eden sosyal dışlanmanın, ayrımcılıkla sıkı bir ilişkisi bulunmaktadır. Nitekim Avrupa Konseyi, sosyal dışlanma tanımı içerisinde "kişilerin ayrımcılık dolayısıyla toplumun dışına itilmesi" ifadesine yer vermektedir. Çalışma hayatı, ayrımcılık, eşitsizlik ve dışlanmanın en belirgin yaşandığı alanı oluşturmaktadır.

Sosyal dışlanma riski yüksek gruplar arasında cinsiyete dayalı ayrımcılığa maruz kalan kadınların bulunduğu görülmektedir. Cinsiyete dayalı ayrımcılık kadınlar açısından firsat eşitsizliği ve işlem eşitsizliklerini de kapsamaktadır. Birbirini besleyen ayrımcılık, eşitsizlik ve dışlanma sarmalında kadınların özellikle çalışma hayatında sorunlar yaşadığı görülmektedir. Hane içinde ve hane dışında kadınların yaşadıkları ayrımcı tutum onları ya çalışma hayatına kabulde ya da çalışma yaşamı içinde eşitsizliklerle dışlanmaya itmektedir. Dikey ve yatay ayrımcılık, fırsat ve işlem eşitsizlikleri kıskacında çalışma hayatında var olma mücadelesi veren kadınların durumunu analiz edebilmek için erkeklere göre konumlarını ortaya koyan verilerden hareket etmek gerekmektedir.

Türkiye, Dünya Bankası tarafından yayımlanan Cinsiyet Ayrımcılığı ve Buna Karşı Verilen Mücadele raporunda (2019) 187 ülke arasında 87. sırada ve Dünya Ekonomik Forumu tarafından yayımlanan Küresel Cinsiyet Eşitsizliği (2021) raporunda 156 ülke arasında 133. sırada yer almaktadır. Ayrımcılık, eşitsizlik ve dışlanmayla mücadeleye yönelik imzalanan uluslararası sözleşmelere, yapılan yasal düzenlemelere ve pozitif ayrımcılık uygulamalarına rağmen Türkiye'de hala eşitsizlik ve dışlanmayla sonuçlanan ayrımcı uygulamaların var olduğu görülmektedir.

Bu bağlamda, çalışmanın amacı ayrımcılık, eşitsizlik ve dışlanma ilişkisi içinde Türkiye'de kadınların çalışma yaşamındaki görünümünü ve mevcut durumu değerlendirmektir. Covid 19 salgın sürecinin değerlendirme kapsamına alınmadığı bu çalışmada, betimsel analiz yöntemi kullanılarak Türkiye işgücü piyasasının güncel verileri analiz edilmektedir.

\section{I- AYRIMCILIK, EŞITTSIZLIIK VE DIŞLANMA İLIŞKİSi}

Adalet, eşitlik, insan hakları konusunda farkındalık ve beklentinin artışıly uluslararası düzeyde ele alınmaya başlanan ayrımcılık sorunu, insan hak ve özgürlükleri önünde önemli engel oluşturmaktadır. Bu sebeple ayrımcılık yasaklarının temelinde insan onuru ve özgürlüklerini korumak yer almaktadır (Çotuksöken, 2010). Günümüz modern ayrımcılık anlayışı içinde anahtar kavram olarak karşımıza çıkan eşitlik, ayrımcılık karşıtlığı söz konusu olduğunda eşit davranma ve eşit işlem görme şeklinde vücut bulmaktadır. Ayrımcılık, insan haklarının uygulama alanını sınırlayarak, eşitliğin hukuksal ve olgusal olarak uygulanması önünde engel oluşturmaktadır. Dolayısıyla eşitlik, eşit işlem yapma ve ayrımcılık yasağı arasında bölünmezlik ilişkisi söz konusudur ve ayrımcılık yapılmaması eşitlik ilkesinin tamamlayıcı unsurunu oluşturmaktadır (Gülmez, 2009: 3-7). Nitekim Avrupa İnsan Hakları Sözleşmesi ve Uluslararası Çalışma Örgütü'nün (ILO) $100^{1}$ ve $111^{2}$ no'lu sözleşmeleri gibi uluslararası metinlerde, eşit işlem yapma ve ayrımcılık yasağı karşılıklı bağımlılık ilişkisi içinde yer almaktadır. İnsan hakları, eşitlik ve ayrımcılık yasağı arasındaki güçlü bağlantının altını çizen Kaboğlu (2002) herkes için yasalar karşısında eşitliğin anayasal ve uluslararası

\footnotetext{
${ }^{1} 100$ Sayılı Eşit Ücret Sözleşmesi (1967).

2111 Sayılı Ayrımcılık (İş ve Meslek) Sözleşmesi (1967). 
hukuk çerçevesinde sayılan, koruma altına alınan evrensel bir hak olduğunu vurgulamaktadır. Öte yandan eşitlikten kastedilenin mutlak eşitlik olmadığını, farklı olma hakkının da eşitlik kavramının görüntüsü olduğunu belirtmektedir. Ancak günümüzde yaşananlar, anayasalar ve kanunlarla tanınmış evrensel hak olan eşitliğe ilişkin soyut hakların, bireylerin moral açısından değersizleștirilmelerine, ikincilleştirilmeleri ve ötekileştirilmelerine tam anlamıyla engel olmadığını göstermektedir (Göregenli, 2012: 1819). Ayrımcılık yasağı, eşitlik ilkesinin somutlaştırılması olmakla birlikte, ayrımcılık ve eşitsizliklerle mücadeleyi ayrımcılık yasağına indirgemek, sadece hukuk ihlali olarak görmek, çok boyutlu bir sorun olan ayrımcılı̆̆ hayatta ayrımcılık şeklinde karşımıza çıkan pek çok davranışın, hukuki olarak ayrımcılık kapsamında yer almadığ 1 ve ayrımcılık sorununun ayrımcılık yasağ 1 ile aynı kavrandığ izlenmektedir. Bu sebeple Gül (2012) ayrımcılık tanımlanırken bireyin ya da grupların hangi özelliklerinden dolayı hangi alanlarda ayrımcılığa maruz kaldıklarının dikkate alınması gerektiğini vurgulamaktadır.

Kanunlar tarafından düzenlenen herkesin eşit olduğuna yönelik yaklaşımın ayrımcılık konusunda yetersiz kalması, sosyal politikaların önemini ortaya koymaktadır. Sosyal devlet olmanın gereği olarak sosyal politikanın bașlıca sorun alanlarından birini olușturan ayrımcılık sorunu karşısında ekonomik ve sosyal yaşamda ortaya çıkan eşitsizlikleri önlemek ve eşitliği sağlamaya yönelik politikaların varlığı önem arz etmektedir (Dedeoğlu, 2009: 42). Sosyal politikanın vatandaşlık hakkı çerçevesinde sosyal barış, sosyal adalet, sosyal bütünleşme hedefleri doğrultusunda ayrımcılığa maruz kalan dezavantajlı birey veya grupları özel önlem ve politikalarla koruyarak, eşit toplum sağlama amacı gütmesi, ayrımcılıkla mücadelede önemli yer teşkil etmektedir (Erikli, 2020: 43-44).

Olumsuz önyargının davranışa dönüşmesini ifade eden ayrımcılık, adil olmayan ve haksız davranışları işaret etmektedir. Ayrımcılık yaşamın her alanında, farklı görünümlerde ortaya çıkmakta ve önyargı duyulan bireyi ya da grubu ekonomik ve sosyal yaşamdan uzak tutmaya, yok saymaya, belirli kaynaklara ulaşımın kısıtlanmasına dayanmaktadır (Erdoğan ve Vatandaş, 2020). Birleşmiş Milletler ve Avrupa Konseyi gibi uluslararası örgütlerce üretilen, Türkiye'nin de imzaladığı temel insan hakları sözleşmeleriyle, insan hakları ihlali olarak kabul görerek yasaklanan ayrımcılık (Uyar, 2006); cinsiyet, yaş, engellilik, etnik köken gibi özellikler nedeniyle öteki olarak görülen birey ya da gruba yönelik olumsuz davranışlar ve tutumlar şeklinde ortaya çıkmaktadır. Ayrımcılık, doğuştan getirilen özelliklerden kaynaklanabildiği gibi birey ya da grubun sonradan elde ettiği özelliklerden dolayı ikincilleştirilmesi, ötekileştirilmesi ve dışlanmaya maruz kalmasını kapsamaktadır (Yıldırım, 2014: 284).

Ulusal ve uluslararası düzeyde ayrımcılığa ilişkin genel kabul gören sınıflandırma bulunmamaktadır. Ancak ILO ortaya çıkış biçimlerine göre ayrımcılığı doğrudan, dolaylı ve sistematik ayrımcılık olarak ayırırken, $\mathrm{AB}$ direktiflerinde taciz, cinsel taciz, emirle ayrımcılığa özendirme, gebeliğe ve analık iznine bağlı ayrımcılık türlerine de yer verilmektedir (Gülmez, 2009).

Tespit edilmesi kolay bir ayrımcılık türü olan doğrudan ayrımcılık, haklı neden bulunmadan, ayrımcılık yasağı getirilmiş nedenlerden herhangi birini baz alarak, hak ve özgürlüklerden aynı ya da benzer konumdakilere göre eşit şekilde yararlanılmasını engelleyen, zorlaştıran farklı muameleyi, dışlanma ve sınırlamayı içermektedir (Gül ve Karan, 2011: 14; Aksaç ve Akdağ, 2015: 8). ILO doğrudan ayrımcılığı, "Kişi veya grupların farklı özellikleri sebebiyle yasal düzenlemeler, politika veya uygulamalarla açık biçimde dışlanması" şeklinde tanımlamaktadır (akt. Yıldırım, 2014: 285). Kadınların ailevi yükümlülükleri sebebiyle iş hayatında etkinlik gösteremeyecekleri yönündeki tutum ve davranışlar doğrudan ayrımcılık 
oluşturmaktadır (Erikli, 2020: 44). Dolaylı ayrımcılık, bazı yasal düzenleme ve uygulamaların görünüşte ayrımcılık olarak anlaşılmasına rağmen bazı kişi ve gruplar üzerinde olumsuz etki yaratmasıdır (Gül ve Karan, 2011: 15). Buna göre hafta sonu ya da mesai saati dışında düzenlenen eğitim faaliyetlerine ailevi yükümlülükleri sebebiyle katılamayan çalışanların dışlanarak, kariyer beklentileri için risk oluşturmak, dolaylı ayrımcılıktır (akt. Yıldırım, 2014: 285). Sistematik ayrımcılık ise toplumda belirli grupların kurumsallaşmış yapılar, politikalar, uygulamalar, gelenekler nedeniyle sürekli biçimde ayrımcılığa uğraması; ayrımcılığın adeta standart uygulama haline dönüşmesidir. Sistematik ayrımcılık, dezavantajlı gruplara yönelik farklı ya da ikinci derece şartlar, eğitim, ulaşım gibi hizmetlerde yetersizlikleri içermektedir. Örneğin yakın zamana kadar Arabistan'da kadınların araba kullanmasının yasak olması bir sistematik ayrımcılıktır (Yıldırım, 2014: 285; Erikli, 2020: 46).

Literatürde yaygın olarak kullanılan ayrım ise negatif ve pozitif ayrımcılık kavramlarında vücut bulmaktadır. Diğer birey ve grupları küçük görmek, aşağılamak, ikincil konuma düşürmek gibi aleyhte yapılan olumsuz davranışları içeren ayrımcılık "negatif ayrımcılık" ve aynı sosyal yapı içinde beraber yaşanılan bireylerin varlığını kabul ederek, kendileri ile aynı şartları sağlamaya yönelik lehte yapılan davranışlar ise "pozitif ayrımcılık" tır. Örneğin aynı işi yapan kadın ve erkek çalışana farklı ücret politikası uygulayarak, kadına düşük ücret verilmesi negatif ayrımcılık oluştururken, özellikle kadınlar lehine düzenlenen kota uygulamaları pozitif ayrımcılık kapsamında değerlendirilmektedir (İspir, 2016: 170). Birçok uluslararası ve ulusal metinde yer bulması sebebiyle pozitif ayrımcılık kavramının ayrımcılıkla mücadelede ön plana çıktığı görülmektedir. Literatürde adil olup olmadığı, ayrımcılık karşıtı hukuka aykırı olup olmadığı yönünde tartışmalar bulunan pozitif ayrımcılık, desteklendiği kadar eleştiri de almaktadır. Pozitif ayrımcılık uygulamalarını savunanlar, adaleti sağlamak, eşitsizliklerin önüne geçebilmek amacıyla katkı sağlayıcılığa vurguda bulunurken, eleştiriler eşitlik ilkesi çerçevesinde yapılmaktadır. Buna göre pozitif ayrımcılık, insan haklarının temeli olan eşitlik ilkesine aykırıdır ve pozitif ayrımcılık uygulamaları yanlış kişilere fayda sağlamak suretiyle hedeflenen sonuçlara ulaşamamaktadır (Akdemir, 2014: 895-896).

Temel insan hakları sözleşmeleri olan İnsan Hakları Evrensel Bildirgesi (1948), Sivil ve Siyasal Haklar Sözleşmesi (1966) ve Ekonomik, Sosyal ve Kültürel Haklar Sözleşmesinde (1966) ayrımcılık yasağı yer almakla birlikte ayrımcılık tanımının yapılmadığı ancak ayrımcı muamelenin kimlere yapılamayacağının sıralandığı dikkat çekmektedir. Buna göre ayrımcılık yasağının belirtilen metinlerde aynı ifadelerle tanımlanarak "Herkes ırk, renk, cinsiyet, dil, din, siyasal ya da başka türden kanaat, ulusal ya da toplumsal köken, mülkiyet, doğuş veya başka türden statü gibi herhangi bir ayrım gözetilmeksizin, bütün hak ve özgürlüklere sahiptir.” şeklinde yer aldığı görülmektedir. Uluslararası sözleşmeler tarafından yasaklanan ayrımcılık türlerinden ilki olan doğrudan ayrımcılık ise "Her Türlü Irk Ayrımcılığının Ortadan Kaldırılması Sözleşmesi”" (1965) ve "Kadınlara Karşı Her Türlü Ayrımcılığın Önlenmesi Sözleşmesi (CEDAW)" nde (1979) açık olarak yer almakta ve ırk ayrımcılığı ile kadın olmaya dayalı ayrımcılığın tanımı net şekilde verilmektedir (Taşğın, 2021: 297-298).

Birleşmiş Milletler Antlaşması ve Birleşmiş Milletlerin temel insan hakları sözleşmeleri dışında Avrupa İnsan Hakları Sözleşmesi (1953), Avrupa Sosyal Şartı (1965) ve Gözden Geçirilmiş Avrupa Sosyal Şartı (1996), AB temel belgeleri ve direktifleri, ILO Anayasası ve sözleşmeleri gibi metinlerle de ekonomik ve sosyal yaşamda ayrımcılık yasağının düzenlendiği görülmektedir (Kaya, 2007; Gülmez, 2009; Korkut, 2009). Türkiye'de, onaylanan uluslararası mevzuatla birlikte ulusal düzeyde Anayasa, İş Kanunu (4857), Sendikalar ve Toplu İş Sözleşmesi Kanunu (6356), Devlet Memurları Kanunu (657), Türkiye 
Ayrımcılık Temelli Dışlanma: Türkiye’de Çalışma Hayatında Kadınlar

İş Kurumu Kanunu (4904), Türk Medeni Kanunu (4721), Türk Ceza Kanunu (5237), Türkiye İnsan Hakları ve Eşitlik Kurumu Kanunu (6701) gibi temel kanunlarla ekonomik ve sosyal yaşamda ayrımcılıkla ilgili yasaklara yer verilmektedir (Yıldırım, 2014: 296-299).

Ayrımcılığı önlemeye yönelik tüm ulusal ve uluslararası düzenlemelere rağmen ayrımcı tutum ve uygulamaların halen devam ettiği ve diğer sorun alanlarını besleyerek, kaynaklık ettiği görülmektedir. Yaş, cinsiyet, etnik köken, engellilik sebebiyle istihdama girememe, kamusal hizmetlerden yararlanmada sorunlar yaşama gibi ayrımcılık örnekleri, ayrımcılığın çeşitlerini de göstermektedir. Buna göre ayrımcılık yaygın olarak cinsiyet ayrımcılığı, yaş ayrımcılığ 1 , ırk ve etnik ayrımcılık, inanca dayalı ayrımcılık ve engelli ayrımcılığı şeklinde yaşanmaktadır (Erdoğan ve Vatandaş, 2020: 480). Sahip olunan bir veya birkaç özellik sebebiyle ayrımcılığa maruz kalma bazı birey veya grupları kategorize ederek dezavantajlı duruma düşürmekte ve sosyal dışlanma, hak kayıpları, eşitsizlik, yoksulluk gibi sorunlar yaşanmasına neden olmaktadır. Nitekim ayrımcılıkla doğrudan ilişkili olan sosyal dışlanmanın Avrupa Konseyi tarafından yapılan tanımında "kişilerin ayrımcılık dolayısıyla toplumun dışına itilmesi” ifadesine yer verilmektedir. Ayrımcılık sebebiyle eğitim, sağlık gibi kamusal alanlarda, hane halkı gibi sosyal alanlarda dışlanmaya maruz kalan grup ve bireylerin, çalışma hayatında da dışlanmaya maruz kaldıkları görülmektedir. Dolayısıyla ayrımcılık, dışlanmanın temel nedenlerinden birini oluşturmaktadır ve ayrımcılık riski altında bulunan kişiler ve gruplar aynı zamanda sosyal dışlanma riski bulunan birey ve gruplardan oluşmaktadır.

Ekonomik boyutu üzerinde durulmakla birlikte sosyal, kültürel ve politik boyutları da bulunan sosyal dışlanma, bireyi ve bazı grupları iş, gelir, temel ve mesleki eğitim, sosyal ilişkiler, kamusal hizmetler gibi ekonomik ve sosyal yaşamın temel alanlarından, ihtiyaçlarından uzaklaştıran, yoksun bırakan bir sorun olarak karşımıza çıkmaktadır (Erdoğdu, 2004). Sosyal dışlanma, "insanların sosyal hayattan uzaklaşacak seviyede maddi ve manevi yoksunluk yaşamaları, gerek hakları gerekse yaşamı koruma altına alacak kurumlar ve sosyal destek mekanizmalarından yoksun olmaları" (Çakır, 2002: 83) şeklinde tüm boyutlarıyla tanımlandığı gibi, ekonomik boyuta vurgu yapan "sermaye birikim sürecinin dışında kalma, ekonomik büyümeye sağladığı katkıdan adil ölçüde yararlanamama" şeklinde de açıklanmaktadır (Sapancalı, 2005: 53). Ekonomik, mekânsal, kültürel ve siyasi dışlanma biçiminde dört temel boyutta kendini gösteren sosyal dışlanmayla mücadele, ayrımcilıkla mücadeleyle birlikte verilmektedir.

Sosyal dışlanmanın nedenlerini açıklamaya yönelik, birbirinden kesin şekilde ayrılan görüşler bulunmaktadır. $\mathrm{Bu}$ görüşler arasında yer alan ayrımcılık ve hak yoksunluğu tartışmaları, karar mekanizmalarında yer alamamanın dışlanmaya neden olduğunu vurgularken, kurumların ve sistemlerin önemine yer veren tartışmalar, grupların ya da bireylerin kurumlara, sistemlere dahil olamama sürecine odaklanmaktadır. Sinıf altı tartışmaları ise birey davranışlarını, ahlaki değerleri esas alarak, dışlanmanın bireyin davranışları sonucu ortaya çıktığına dayanmaktadır (Burchardt, Le Grand ve Piachaud, 2002: $3-4)$.

Avrupa Birliği'nde sosyal dışlanma riski yüksek olan gruplar incelendiğinde, toplumsal cinsiyete dayalı ayrımcılığa maruz kalan kadınlara yer verildiği izlenmektedir. Ayrımcılık türleri arasında yer alan cinsiyete dayalı ayrımcılık temelde kadınlar, erkekler ve cinsel yönelimi farklı olan bireyleri kapsamaktadır. Ancak başta ataerkil toplum yapısına sahip ülkeler olmak üzere hemen her ülkede cinsiyete dayalı ayrımcılık sorununu ağırlıkla kadınlar yaşamaktadır. Bu sebeple cinsiyet ayrımcılığı söz konusu olduğunda ilk olarak, dünya nüfusunun yarısını oluşturan ancak toplumda hala ikinci sınıf görülen, toplumsal yaşamın her alanında varlık göstermesi engellenen kadınlar akla gelmektedir. 
Cinsiyete dayalı ayrımcılığa maruz kalan kadınlar, sosyal dışlanmanın tüm boyutlarını yaşamaktadır. $\mathrm{Bu}$ durum kadınların yoksulluk sorununu da erkeklerden daha derin yaşamasına neden olarak, kadın yoksulluğu sorununu da ortaya çıkarmaktadır. Eşitsizliklerin temelini oluşturan cinsiyet ayrımcılığı, sosyal dışlanmanın tüm boyutlarında kendini göstermekle birlikte kadınları yoksulluk gibi derinleşen sorunlarla da karşı karşıya bırakan temel boyutun çalışma hayatından dışlanmada ortaya çıktığı izlenmektedir. Dolayısıyla cinsiyete dayalı ayrımcılığın ve cinsiyet eşitsizliğinin en görünür olduğu alanı çalışma hayatı oluşturmaktadır. Nitekim istihdam, işsizlik alanına yönelik çalışmalarda toplumsal cinsiyeti ve cinsiyet ayrımcılığını hesaba katmayan yaklaşımın ciddi eksiklik oluşturacağı vurgulanmaktadır (Ecevit, 2011a). Cinsiyete dayalı ayrımcılıkta, ataerkil yapı gücünü sadece ailede değil, kapitalist pazarda da göstermektedir. Kadının çalışmaya katılımının kontrolünde hane içi ilişkiler kadar hane dışında kalan, işyerindeki ataerkil ilişkiler ve devlet de belirleyici olmaktadır. Ataerkil yapı içinde bakım gibi hane organizasyonu ve kadının çalışmasına eşin, aile bireylerinin bakışı, izni gibi aile içi ilişkiler, hane içi etkileri oluştururken (Kandiyoti, 1988; Dedeoğlu, 2004), işverenlerin cinsiyete dayalı önyargı, tutum ve davranışları hane dışı etkileri oluşturmaktadır.

Ataerkil yapının kadını çalışma yaşamından alıkoyması, çalışmamanın kadının bireysel tercihi olduğu şeklindeki tartışmaların, çalışma hayatından dışlanmayı değerlendirmede tek başına yeterli olmadığını söylemek mümkündür (Ecevit, 2011b: 108-112; Toksöz, 2017). Bu kapsamda kadınları çalışma hayatından dışlayan ayrımcılığın, fırsat ve işlem eşitsizlikleriyle değerlendirilmesi önem arz etmektedir (Erdut, 2006: 3-4). Çalışma yaşamında pozitif ayrımcılık uygulamalarına rağmen kadınların dışlanma yaşamalarının önüne geçilemediği görülmektedir. Literatürde de Türkiye'deki reform süreci içerisinde kanunlarda düzenlemeler yapılmasına rağmen, erkeklere verilen hakların kadınlara verilmesinin gerçekten kadınlar için eşitlik getirip getirmediği, uygulanan politikaların gerçek hayatta eşitsizlikleri ve ayrımcılığı önleyip önlemediği tartışılmaktadır (Dedeoğlu ve Elveren, 2017; Toksöz, 2017; Dedeoğlu, 2017; Şahin, 2017).

\section{II- TÜRKIYE'DE AYRIMCILIK TEMELLİ DIŞLANMA: ÇALIŞMA HAYATINDA KADINLAR}

Çalışma hayatında dışlanma yaşayan kadınların ayrımcılık sorunu, eğitim ve mesleki eğitim edinmede firsat eşitsizlikleri ile başlamakta, istihdama giriş süreçlerinde ve istihdam içinde yaşadıkları ücret farklılıkları gibi işlem eşitsizlikleriyle devam etmektedir (Çakır, 2008: 42). Ayrıca kadınların önemli kesiminin kayıt dışı, sosyal güvenceden yoksun, düşük nitelikli, tekrara dayalı işlerde çalıştıkları, sendikal örgütlenme oranlarının düşük olduğu bilinmektedir.

CEDAW cinsiyete dayalı ayrımcılığı, "Başta kadının insan hakları ve temel özgürlükleri olmak üzere, sahip olduğu politik, ekonomik, sosyal, kültürel, medeni hakların kullanılmasını engellemeye yönelik her türlü eylem" olarak tanımlamaktadır (Erikli, 2020: 46). Çalışma hayatında cinsiyete dayalı ayrımcılık, yatay ayrımcılık ve dikey ayrımcılık şeklinde karşımıza çıkmaktadır. Yatay ayrımıılık, mesleklerin kadın işi-erkek işi şeklinde ayrışmasını ve belirli mesleklerde kadınların işe seçilmemesi/yerleştirilmemesini ifade eden meslek ayrımcılığı ve aynı işi yapan kadın ve erkeğe, cinsiyet farklılığı nedeniyle eşit işe eşit ücretin ödenmemesi durumunu ifade eden ücret ayrımcılığı şeklinde ikiye ayrılmaktadır. Dikey ayrımcılık ise kadınların cinsiyetleri sebebiyle karar alma/verme ve yönetim süreçlerinden dışlanmasını, terfi ve kariyer süreçlerinde erkeklerle eşit firsatlara sahip olamamasıdır (ILO, 2009: 5; Alparslan vd. 2015: 65-67; Parlaktuna, 2010: 1222). Ayrıca kadınların birincil görevinin ailevi sorumluluklar, bakım ihtiyacı sağlama olarak görülmesi sebebiyle işlerine gereken özeni gösteremeyecekleri, verimli olamayacakları, evlenene ya da çocuk sahibi 
oluncaya kadar geçici süre çalışacakları, evin geçiminden doğrudan sorumlu olmadıkları gibi düşüncelerle işe alımlarda ayrımcılığa uğradıkları ve işten çıkarmalarda erkeklerden önce akla geldikleri izlenmektedir. Bu durum cinsiyete dayalı ayrımcılıkta etkili olan ataerkil yapının hane dişındaki görünümünü sergileyerek, işlem eşitsizliği doğurduğunu ortaya koymaktadır. Ecevit (2011b) de ataerkil ilişskiler ve ayrımcı tutumun, işgücü piyasasında kadınların çalışma yaşamından dışlanması sorununu açıklamak bakımından önemli göstergelere sahip olduğunu ifade ederek, bu göstergeleri; belirli iş ve mesleklerde kadınların düşük oranda kabulü, bekar, çocuksuz kadınların işe alımda tercih edilmesi gibi eşitsizlik içeren uygulamalar, ücret eşitsizliği oluşturan ayrımcı uygulamalar, kriz dönemlerinde kadınların erkeklerden önce işten çıkarılması, sendika yönetim kadrolarında kadın temsilinin az olması şeklinde sıralamaktadır.

Çalışma hayatında kadının konumu, geliri gibi ekonomik ve sosyal değişkenleri negatif etkileyen, ayrımcılık ve dışlanma ortaya çıkaran temel nedenlerden birini eğitim ve meslek edinmede yaşanan fırsat eşitsizliği oluşturmaktadır. Gelir dağılımı adaletsizliği ve yoksulluğun da firsat eşitsizliği yaratarak ayrımcılığa ve dışlanmaya kaynaklık ettiği görülmektedir (Çakır, 2008: 30-32). Zaman kullanımında toplumsal cinsiyet odaklı farklılıklara ve dolayısıyla hane içi eşitsizliklere bakıldığında, ev/aile işi yükünden dolayı kadınların çalışma yaşamında daha dezavantajlı duruma geldikleri, böylece işgücü piyasasındaki eşitsizliği geri besledikleri görülmektedir (Memiş vd., 2017: 160-162).

Çalışma yaşamında dışlanmayı, kadınların firsat eşitsizliği ve işlem eşitsizliği gibi ayrımcılık kaynaklarını içerecek şekilde eğitim, temel işgücü göstergeleri, ücretler, kayıtlılık durumu, üst yönetimde yer alma ve sendikal örgütlenme temaları üzerinden analiz etmek mümkündür.

Türkiye İstatistik Kurumu (TÜİK, 2021a) verilerine göre Türkiye'de toplam nüfusun \%49,9'unu kadınlar, \%50,1'ini erkekler oluşturmaktadır. Türkiye'de kadın işgücü potansiyelinin önemli bölümünün kullanılmadığı bilinmektedir. "Her Alandaki Kadın İstihdamının Artırılması ve Çözüm Önerileri Komisyon Raporu"nda kadın istihdamının artması önündeki engeller; iş ve aile yaşamının uyumlaştırılamaması, toplumsal cinsiyet eşitliğinin sağlanamaması, eğitim alanında karşılaşılan sorunlar, kadın girişimciliğinin yetersiz olması şeklinde sayılmaktadır (Metin ve Kariman-Arabacı, 2013).

\section{A- Eğitim, Ayrımcılık ve Dışlanma İlişkisi Teması}

Toplumsal cinsiyet rolleri ve eğitim düzeyi kadının işgücüne katılımı, ayrımcılık, eşitsizlik, dışlanma sorunları yaşaması açısından belirleyicidir. Eğitimde cinsiyete dayalı ayrımcılık, eğitimde firsat eşitsizliği olarak tanımlanmakta ve coğrafi, sosyal ve ekonomik etkenler de bu firsat eşitsizliğini destekleyerek, kadınların toplumsal hayata katılımına engel oluşturmaktadır (Çakır, 2008: 30). Eğitim ve meslek edinmede firsat eşitsizliği yaşayan kadınlar, çalışma hayatına girerken ve çalışma yaşamının içerisinde dişlanma sorunuyla karşılaşmaktadırlar. Yıllar itibariyle işgücü piyasasında düşük eğitim sorunu cinsiyet bazında değerlendirildiğinde bu durumun daha çok kadın sorunu olduğu, özellikle mesleki eğitime yapılan yatırımların kadınların kayıtlı işler bulabilmesi, toplumsal cinsiyet eşitliğinin sağlanabilmesi açısından önemli olduğu ifade edilmektedir (ILO, 2008). Kadınların bireysel özgürlüğünün sağlanması, ikincil konumdan kurtulmanın anahtarı olan eğitim, çalışma hayatına katılım, ücret seviyesinin yükselmesi gibi imkanları sağlarken, ayrımcılığa sebep olan zihniyetin değişmesi açısından da önemlidir (Önder, 2013:49-50). Ayrıca kadınların eğitimi ve istihdam ile ekonomik büyüme ilişkisini Türkiye açısından inceleyen araştırmalar, eğitimli kadın istihdamında artışın ekonomik büyümeyi önemli ölçüde desteklediği sonucuna ulaşmaktadır (İnce, 2011; Serel ve Özdemir, 2017). 
Tablo 1. Cinsiyet ve Eğitim Durumuna Göre İs̆gücü Durumu (\%), 2019

\begin{tabular}{lllllll}
\hline & \multicolumn{2}{l}{ İşücüne Katıım Oranı } & İstihdam & \multicolumn{3}{l}{ İşsizlik } \\
\cline { 2 - 7 } & Kadın & Erkek & Kadın & Erkek & Kadın & Erkek \\
\hline Okuryazar Olmayanlar & 15,4 & 32,1 & 14,5 & 26,6 & 5,8 & 17,2 \\
\hline Lise altı Eğitimliler & 28,0 & 68,1 & 24,2 & 59,1 & 13,4 & 13,1 \\
\hline Lise & 34,1 & 71,3 & 26,3 & 61,8 & 22,8 & 13,3 \\
\hline Mesleki ve Teknik Lise & 42,2 & 80,8 & 31,3 & 71,5 & 25,8 & 11,5 \\
\hline Yükseköğretim & 71,5 & 85,8 & 58,3 & 77,0 & 18,5 & 10,3 \\
\hline
\end{tabular}

Kaynak: TÜiK, İstatistiklerle Kadın, 2021a

TÜİK'in güncel verilerine göre 2019'da en az bir eğitim düzeyini tamamlayanların oranı kadınlarda \%85,7, erkeklerde \%96,4 olarak gerçekleşmiştir. En az üniversite mezunu olan 25 ve daha yukarı yaştaki nüfus cinsiyete göre incelendiğinde kadınlarda oranın \%18,5, erkeklerde \%23,1 olduğu görülmektedir. Tablo 1 incelendiğinde eğitim seviyesinin kadınların işgücüne katılımını önemli ölçüde etkilediği izlenmektedir. Kadınların eğitim seviyesi arttıkça istihdam oranı artmaktadır. Ancak işsizlik oranlarına bakıldığında kadınların işsizlik oranlarının erkeklerden fazla olduğu, eğitim düzeyindeki artışın işsizlik sorunu üzerinde beklenen etkiyi yaratamadığı görülmektedir. $\mathrm{Bu}$ durum çalışma yaşamında toplumsal cinsiyete dayalı ayrımcılığın etkisini göstermektedir.

Mesleki ayrımcılığı eğitim ve toplumsal cinsiyet boyutuyla inceleyen Parlaktuna (2010: 1223), kırsal kesimde çalışan kadınların yoğunlukla ücretsiz aile işçisi olmalarının sadece düşük eğitimle açıklanamayacağı, kültürel olarak tarım sektörünün kadınlar için kabul gören istihdam olduğu ve eğitim, evlilik gibi piyasa öncesi tercihlerin etkilerinin göz ardı edildiğini vurgulamaktadır. Kentsel kesimde çalışan kadınları düşük ve yüksek eğitimli olarak ayırarak, iki grubun da cinsiyete dayalı ayrımcılık yaşadıklarını ancak sorunların farklılık gösterdiğini belirtmektedir. Parlaktuna'ya göre düşük eğitimli kadınlar daha çok yatay ayrımcılık, yüksek eğitimli kadınlar ise dikey ayrımcılıkla ilgili sorunlar yaşamaktadır. Çalışmada ayrıca kentsel alanda düşük eğitimli kadınların ya formel sektörde çalışma koşulları kötü, düşük ücretli işlerde ya da enformel sektörde çalışmak zorunda kaldıkları veya çalışma hayatı dışına çıkarak ev kadını oldukları vurgulanmaktadır. Eğitimde fırsat eşitsizliği, gelir eşitsizliği açısından da önemlidir. Eğitim durumuna göre cinsiyetler arası gelir eşitsizliğini inceleyen Çolak (2021), yükseköğretim mezunu kadınların gelir eşitsizliğini en az yaşayan eğitim grubuna sahip olduğu sonucuna ulaşmaktadır. 
Ayrımcılık Temelli Dışlanma: Türkiye'de Çalışma Hayatında Kadınlar

\section{B- Temel İşgücü Göstergeleri, Ayrımcılık ve Dışlanma İlişkisi Teması}

Tablo 2. Temel İsgücü Göstergeleri (\%), 2020

\begin{tabular}{lllll}
\hline & & İKO & İstihdam & İşsizlik \\
\hline Kadın & $\mathbf{2 0 1 9}$ & 34,4 & 28,7 & 16,5 \\
\cline { 2 - 5 } & $\mathbf{2 0 2 0}$ & 30,9 & 26,3 & 15,0 \\
\hline \multirow{2}{*}{ Erkek } & $\mathbf{2 0 1 9}$ & 72,0 & 63,1 & 12,4 \\
\cline { 2 - 5 } & $\mathbf{2 0 2 0}$ & 68,2 & 59,8 & 12,3 \\
\hline
\end{tabular}

Kaynak: TÜİK, İşgücü İstatistikleri, 2021b

Tablo 2 değerlendirildiğinde, kadınların işgücüne katılma oranı 2020 yılında \%30,9, erkeklerin işgücüne katılma oranı \%68,2 şeklinde gerçekleşmiştir. İstihdam ve işsizlik verileri cinsiyetler açısından değerlendirildiğinde, 2020'de istihdam oranının kadınlarda $\% 25,3$, erkeklerde $\% 59,8$ olarak gerçekleștiği görülmektedir. İstihdam oranları kadınlarla erkekler arasında belirgin bir farklılığı işaret etmektedir. İşsizlik oranları ise kadınlarda 2020 yılında \%15,0, erkeklerde ise \%12,3 olarak gerçekleşmiştir.

2020 yılında 21 milyon 855 bin kadının işgücüne dahil olmadığı ve işgücüne dahil olmama nedenlerinin başında ev işleriyle meşguliyetin (10 milyon 308 bin) yer aldığ görülmektedir. Bedensel engel, hastalık veya yaşlılık, eğitim-öğretimde bulunmak ve diğer nedenler arasında yer alan ailevi ve kişisel sebepler sırasıyla kadınların işgücüne dahil olmama nedenlerini oluşturmaktadır. Erkeklerin durumu incelendiğinde nedenler arasında kadınlarda ilk sırada yer alan ev işleri ile meşguliyetin bulunmadığ 1 görülmektedir. İşgücüne dahil olmama nedenleri arasında yer alan eğitim-öğretimde bulunmanın kadın ve erkekler için birbirine yakın olması, kadınların eğitime erkekler kadar dahil olduğunu göstermektedir (TÜiK, 2021b).

Tablo 3. İsgücüne Dahil Olmama Nedenleri (Bin Kişi)

\begin{tabular}{lllll}
\hline İşgücüne Dahil Olmama Nedenleri & Kadın & \multicolumn{3}{c}{ Erkek } \\
\hline & $\mathbf{2 0 1 9}$ & $\mathbf{2 0 2 0}$ & $\mathbf{2 0 1 9}$ & $\mathbf{2 0 2 0}$ \\
\hline İş Aramayıp Çalışmaya Hazır Olanlar & 1406 & 2373 & 880 & 1850 \\
\hline Mevsimlik Çalışanlar & 68 & 60 & 35 & 47 \\
\hline Ev İşleriyle Meşguliyet & 11.359 & 10308 & 0 & 0 \\
\hline Eğitim-Öğretimde Bulunma & 2286 & 2408 & 2089 & 2105 \\
\hline Emekli & 1250 & 1281 & 3710 & 3605 \\
\hline Çalışamaz Halde & 2626 & 3313 & 1279 & 1555 \\
\hline Diğer & 1416 & 2112 & 517 & 691 \\
\hline
\end{tabular}

Kaynak: TÜİK, İşgücü İstatistikleri, 2021b 
Kadınların nedenleri arasında ilk sırada bulunan ev işleriyle meşguliyeti, ayrımcılık ve eşitsizliğe sebep olması açısından ayrıca değerlendirmek gerekmektedir. Daha önce değinildiği gibi kadına biçilen rol, işgücü piyasasında yaşanan ayrımcılığı ve eşitsizliği geri beslemektedir. Literatürdeki çalışmalar evdeki iş ve bakım yükünün, evli ve özellikle 0-5 yaş arası küçük çocuk sahibi olmanın kadınların çalıșma kararında önemli rol oynadığını ve hatta işgücüne katılma ihtimalini düşürdüğünü, işgücüne katılım biçiminin ev içi roller çerçevesinde belirlendiğini ortaya koymaktadır (Eyüpoğlu vd. 2000; Başlevent ve Onaran, 2003; İlkkaracan 2012; Dedeoğlu, 2010).

TÜİK İstatistiklerle Kadın (2021a) sonuçlarına göre hanesinde 3 yaş altı çocuğu olan 25-49 yaş grubundaki kadın istihdam oranı $\% 26,7$ iken erkeklerinki \%87,3 olarak gerçekleşmiştir. Medeni duruma göre istihdama katılım oranına bakıldığında evli kadınların \%27,6'sının, erkeklerin ise \%66,7'sinin istihdama katıldığ 1 ; hiç evlenmeyen kadınların \%29,6'sının, boşanan kadınların \%37'sinin, eşi vefat eden kadınların \%6,5'inin istihdama katıldığg görülmektedir. Erkeklerde ise hiç evlenmemiş erkeklerin \%48,7'sinin, boşanmış olanların $\% 58,7$ 'sinin ve eşi vefat edenlerin \%15,9'unun istihdama katıldığ 1 izlenmektedir (TÜiK, 2021b). TÜIKK Zaman Kullanım Araştırması 2015 yılı sonuçlarında hanehalkı ve aile bakımına ayrılan zaman, çalışma durumuna ve cinsiyete göre incelendiğinde; çalışan kadınların günde ortalama 3 saat 31 dakika, çalışan erkeklerin 46 dakika ayırdığı, çalışmayan kadınlarda bu oranın 4 saat 59 dakika olduğu görülmektedir (TÜİK, 2015). İstatistikler, Türkiye'de geleneksel toplumsal cinsiyetçi iş bölümünün varlığını, kadınların zamanlarının önemli bölümünü karşılıksız çalışma faaliyetlerine ayırdıklarını ve eşitsizliğin büyüklüğünü göstermektedir.

Çalışma yaşamından dışlanmaya neden olan eşitsizlikleri gösteren bir başka araştırma da Aile Yapısı Araştırması'dır. Buna göre hanedeki 0-5 yaş çocukların bakımını hanelerin \%86'sında annelerin üstlendiği (TÜİK, 2017), bakıma muhtaç hastanın bulunduğu hanelerde bakım işinin yine kadınlar tarafından üstlenildiği görülmektedir. Araştırma bulguları, evin gündelik ve düzenli yapılan temizlik gibi işlerinin \%80-\%88 oranlarında kadınlarca yapıldığını ortaya koymaktadır. Türkiye Aile Yapısı İleri İstatistik Analizinde de istihdamdaki evli kadınların evin günlük toparlanması ve temizliği gibi ev işlerini yapma oranı erkeklerden fazla olarak tespit edilmiştir (TAYA, 2019a; TAYA, 2019b). 2018 yılı Türkiye Nüfus ve Sağlık Araştırması'na göre de çocuk bakımı (\%21), ev kadını olma (\%20), öğrenci olma (\%17) ve eş ya da ailenin çalışmaya izin vermemesi (\%11) kadınların işgücüne katılmama nedenlerini oluşturmaktadır (NEE, 2019: 182). Araştırmalar, vardiya veya çifte mesai tezlerini doğrular nitelikte bir sonuç olarak Türkiye'de çalışan kadınların çift mesai yaptıklarını göstermektedir. Hane içindeki eşitsizlikler, kadınların işgücüne katılımı önünde önemli bir engel oluşturmaktadır. Kadın Erkek Fırsat Eşitliği Komisyonu da kadın istihdamı önünde engel olarak saydığı cinsiyete dayalı eşitsizliğin temel nedenleri arasında, toplumsal cinsiyete dayalı geleneksel iş bölümüne, iş-aile yaşamını uzlaştırıcı mekanizmaların yetersizliğine vurguda bulunmaktadır (Metin ve Kariman, 2013). Türkiye'de Kadın Emeği Raporu (DİSK, 2020), 2019'da 494 bin kadının ev içi bakım hizmetlerini sağlamak için işinden ayrıldığına, erkeklerde ise 14 bin kişinin ailedeki çocuklara veya bakıma muhtaç yetişkinlere bakmak için işten ayrıldığına yer vermektedir.

Kadınların yaşadığı ayrımcılık, istihdamın sektörel dağılımında da izlenmektedir. Ülkenin gelişmişlik düzeyinin de önemli bir göstergesi olan istihdamın sektörel dağılımı Tablo 4'te incelendiğinde kadın ve erkeklerin ağırlıklı olarak hizmet sektöründe yer aldıkları, kadınların yoğunlukta olduğu ikinci sektörün tarım ve üçüncü olaraksa sanayi sektörünün geldiği görülmektedir. Teknik bilgi gerektiren işlerin erkek işi olduğu yönündeki toplumsal cinsiyetçi tutum, sanayi sektöründe kadınların istihdamına yönelik engel ve kısıtlar doğurmaktadır.

Dolayısıyla cinsiyete dayalı mesleki ayrımcılı̆̆ı, sanayi sektöründe kadın istihdam oranının erkeklerden düşük kalmasına neden olmaktadır. 
Ayrımcılık Temelli Dışlanma: Türkiye’de Çalışma Hayatında Kadınlar

Tablo 4. İstihdamin Sektörel Dă̆ıllımı (\%)

\begin{tabular}{lllll}
\hline & & Tarım & Sanayi & Hizmet \\
\hline Kadın & $\mathbf{2 0 1 9}$ & 25,1 & 15,9 & 59,0 \\
\cline { 2 - 5 } & $\mathbf{2 0 2 0}$ & 22,8 & 16,8 & 60,4 \\
\hline \multirow{2}{*}{ Erkek } & $\mathbf{2 0 1 9}$ & 14,9 & 29,7 & 55,4 \\
\cline { 2 - 4 } & $\mathbf{2 0 2 0}$ & 15,3 & 30,5 & 54,3 \\
\hline
\end{tabular}

Kaynak: TÜIK, İstatistiklerle Kadın, 2021a.

Türkiye'de üretimin sanayi ve hizmet sektörlerine kaydığı, nüfusun kentlerde yoğunlaştığı ve toplumsal yapının dönüştüğü bilinmektedir. Bu gelişmeler kadınların hizmet sektöründe istihdama katılımını arttırmaktadır. Bu sektörde kadın istihdamının artmasının nedenlerinin başında, sektördeki birçok çalışma alanının "kadınlara uygun” özellik taşıması ve esnek çalışma biçimlerine uygun olması gelmektedir. TÜİK verilerinde cinsiyete göre yarı zamanlı çalışanların istihdam içindeki oranına bakıldığında da kadınların yarı zamanlı çalışanlar içindeki oranı erkeklerden fazladır. 2019 yılında yarı zamanlı çalışanlar içinde kadınların oran $1 \% 17$, 4, erkeklerin oran $1 \% 7,1$ iken 2020 yılında kadınların oran $\% 19,5$, erkeklerin oranı \%9,3 şeklinde gerçekleşmiştir (TÜİK, 2021b). Hizmet sektörü, işgücüne katılım biçiminin ev içi roller çerçevesinde belirlendiği cinsiyetçi yapıda kadınlar için önemli bir çalışma alanı oluşturmaktadır. Ancak hizmet sektörünün hane içi engelleri aşsa da hane dışı engellere takılmadığını ve bu sektörün kadınlar açısından eşitlikçi yapı sergilediğini söylemek mümkün değildir.

2020 yılı iktisadi faaliyet kollarına göre TÜİK verileri incelendiğinde, kadın istihdamında sırasıyla ilk beşte; tarım, orman ve balıkçılık faaliyetleri, imalat faaliyetleri, toptan ve perakende ticaret faaliyetleri, eğitim faaliyetleri ve insan sağlı̆ 1 , sosyal hizmet faaliyetlerinin yer aldığı izlenmektedir. Erkeklerin iktisadi faaliyetlerinde ise eğitim faaliyetleri, insan sağlığı ve sosyal hizmet faaliyetleri ilk beşte yer almamaktadır.

Tablo 5. İsteki Duruma Göre İstihdam Edilenler (\%)

\begin{tabular}{lccccc}
\hline & & $\begin{array}{c}\text { Ücretli, Maaşlı } \\
\text { ve Yevmiyeli }\end{array}$ & İşveren & $\begin{array}{c}\text { Kendi Hesabına } \\
\text { Çalışanlar }\end{array}$ & $\begin{array}{c}\text { Ücretsiz Aile } \\
\text { İşçisi }\end{array}$ \\
\hline Kadın & $\mathbf{2 0 1 9}$ & 66,6 & 1,4 & 9,0 & 23,0 \\
\cline { 2 - 5 } & $\mathbf{2 0 2 0}$ & 69,0 & 1,8 & 9,1 & 20,2 \\
\hline \multirow{2}{*}{ Erkek } & $\mathbf{2 0 1 9}$ & 69,3 & 5,9 & 20,4 & 4,5 \\
\cline { 2 - 5 } & $\mathbf{2 0 2 0}$ & 70,2 & 5,7 & 19,8 & 4,3 \\
\hline
\end{tabular}

Kaynak: TÜİK, İstatistiklerle Kadın, 2021a 
İşteki duruma göre istihdam edilenler cinsiyete göre değerlendirildiğinde ücretli, maaşlı ve yevmiyeli istihdam edilen kadınların oran 2019 yılında \%66,6, 2020 y1lında \%69, erkeklerin oranı 2019 yılında \%69,3 ve 2020 yılında \%70,2 olarak görülmektedir. Kadınların ücretli, maaşlı ve yevmiyeli istihdam edilme oranının yıllar itibariyle yükselmesiyle cinsiyetler arasındaki farklılık azalış göstermiş olsa da kadın oranı erkek oranının gerisinde kalmaya devam etmektedir. Ücretli çalışmaya katılan kadın oranında ve statüsünde değişim ve iyileşme görülmekle birlikte işlem eşitsizliği olarak kendini gösteren işten çıkarmalarda kadınları erkeklere göre dezavantajlı kılan ayrımcılık da yaşanmaya devam etmektedir. Zira kadınlar kriz dönemlerinde işten çıkarmalarda ilk akla gelen grubu oluşturmaktadır. Ayrıca birçok ülkede işsizlik ve uzun süreli işsizlik yaşayanlar içinde kadın oranı, erkek oranından yüksek seyretmektedir (İleri, 2016: 140-141). TÜİK istatistiklerinde, cinsiyetler arası çalışma hayatında kalma süresi arasındaki farklılık da dikkat çekmektedir. Kadınların yıllar itibariyle çalışma hayatında kalma süresi artmış olsa da ${ }^{3} 2019$ yılı verilerine göre kadınların ortalama olarak 19,1 yıl, erkeklerin ise 39 y1l olarak belirtilmektedir (TÜIKK, 2021b).

İşteki duruma göre kadınların ücretsiz aile işçiliği oranının azaldığı, ücretli, maaşlı ve yevmiyeli oranının arttığı izlenmektedir. Ancak ücretsiz aile işçisi olan kadınların tamamına yakınının sosyal güvenlik dışında kaldığı unutulmamalıdır. Ücretsiz aile işçisi oranı kıyaslandığında kadın ve erkekler arasında önemli fark olduğu görülmektedir. İşteki durum, cinsiyet açısından önemli bir karşılaştırma imkanı sunarken, sosyal güvence ve etkin sosyal diyalog mekanizmalarından yoksun şekilde, yeterli gelir elde edemeden, temel işçi haklarından yararlanamadan çalışmayı ifade eden savunmasız (korunmasız) istihdam boyutunu değerlendirmek ve erkek istihdamıyla karşılaştırma yapabilme açısından da önem arz etmektedir. Savunmasız (korunmasız) istihdam; kendi hesabına çalışanlar ve ücretsiz aile işçilerini savunmasız, işverenler ve ücretli, maaşlı, yevmiyeli çalışanları ise daha az savunmasız olarak iki yönlü bir sınıflandırma altında toplamaktadır. Buna göre savunmasız istihdam boyutuyla cinsiyetler işteki duruma göre karşılaştırıldığında, kadınların savunmasız istihdama erkeklere göre daha fazla maruz kaldığı görülmektedir (Öcal, 2021: 816-817).

İşveren ve kendi hesabına istihdam oranlarında da erkek istihdam oranının, kadın oranından yüksek olduğu izlenmektedir. Türkiye'de toplumsal cinsiyet perspektifinden girişimciliğin tartışıldığı ve cinsiyet eşitsizliklerinin azaltılmasında kadın girişimciliğinin önemine yer veren çalışmalarda, toplumsal cinsiyet algısının kadın girişimci sayısının temel belirleyicilerinden olduğu ifade edilmektedir (Seçkin Halaç ve Meşe, 2021). Ayrıca bu çalışmalar, kadın girişimciliğinin odak noktasının çok kısa sürede değişerek, kadının güçlenmesinden ziyade hane halkının güçlenmesine, kadına yönelik faydadan ziyaden hane halkının faydasına yöneldiğine de dikkat çekmektedir (Ecevit, 2007; Sallan Gül ve Altındal, 2016; Çitçi ve Sağır, 2017; Tunç, 2018). Öte yandan ayrımcılığa ve eşitsizliğe neden olan toplumsal önyarg1 ve baskılar nedeniyle kadınların işgücüne katılımda girişimciliği tercih etmelerinin bir seçimden daha çok tek alternatif olarak görülebileceği de belirtilmektedir (Seçkin-Halaç ve Seçkin-Çelik, 2018). Global Girişimcilik İzleme Raporu'na (2019) göre Türkiye, kadın girişimcilerin erkek girişimcilerin yarısından daha az oranda olduğu ülkeler arasında yer almaktadır (KAGIDDER, 2019). Girişimcilik Araştırması'na göre ise 2018 yılı için kadın işverenlerin toplam işverenler içerisindeki payı \%8,7, hukuki durumu ferdi mülkiyet ve sahibi kadın olan işveren girişimlerin oranı $\% 19,3$ iken erkeklerde söz konusu oranlar sirasıyla \%91,3 ve \%80,7 olarak belirtilmektedir (TÜİK, 2020).

\footnotetext{
32013 yılında 15 ve daha yukarı yaştaki kadınlarda çalışma hayatında kalma süresi 16,7 yıl olarak ifade edilmektedir. Buna göre kadınların çalışma hayatında kalma süresinin 7 yılda 2,4 yıl arttığı görülmektedir (TÜIKK, 2020).
} 
Ayrımcılık Temelli Dışlanma: Türkiye’de Çalışma Hayatında Kadınlar

Yapılan araştırmalar ve istatistiki veriler, kadınların yatay ayrımcılık olan cinsiyete dayalı meslek ayrımcılığı hususunda da erkeklere göre dezavantajlı durumda olduğunu göstermektedir. Bu durum, kadının çalışma hayatındaki konumu, eğitimi, geliri gibi sosyal değişkenlerini de olumsuz etkileyerek (Parlaktuna, 2010: 1218), eşitsizliklerin artmasına neden olmaktadır. Meslek gruplarına göre dağılım cinsiyete dayalı ayrımcılığın çalışma yaşamındaki yansımasını ortaya koymaktadır.

Tablo 6. Cinsiyete Göre İstihdamın Meslek Grubuna Göre Dağılımı (Bin kişi)

\begin{tabular}{|c|c|c|c|c|}
\hline \multirow[t]{2}{*}{ Meslek Grubu } & \multicolumn{2}{|c|}{ Kadın } & \multicolumn{2}{|c|}{ Erkek } \\
\hline & 2019 & 2020 & 2019 & 2020 \\
\hline Yöneticiler & 244 & 273 & 1.260 & 1.229 \\
\hline Profesyonel Meslek Mensupları & 1.486 & 1.551 & 1.671 & 1.747 \\
\hline $\begin{array}{l}\text { Yardımcı Profesyonel Meslek } \\
\text { Mensupları }\end{array}$ & 480 & 465 & 1.239 & 1.177 \\
\hline $\begin{array}{l}\text { Büro ve Müşteri Hizmetlerinde } \\
\text { Çalışanlar }\end{array}$ & 840 & 796 & 1.109 & 1.078 \\
\hline Hizmet ve Satış Elemanları & 1.915 & 1.726 & 3.758 & 3.464 \\
\hline $\begin{array}{l}\text { Nitelikli Tarım, Ormancılık ve } \\
\text { Su Ürünlerinde Çalışanlar }\end{array}$ & 1.499 & 1.244 & 2.477 & 2.403 \\
\hline $\begin{array}{l}\text { Sanatkârlar ve İlgili İşlerde } \\
\text { Çalışanlar }\end{array}$ & 447 & 433 & 3.072 & 2.944 \\
\hline $\begin{array}{l}\text { Tesis ve Makine Operatörleri ve } \\
\text { Montajcılar }\end{array}$ & 303 & 278 & 2.289 & 2.146 \\
\hline $\begin{array}{l}\text { Nitelik Gerektirmeyen İşlerde } \\
\text { Çalışanlar }\end{array}$ & 1.712 & 1.541 & 2.281 & 2.318 \\
\hline
\end{tabular}

Kaynak: TÜiK, İstatistiklerle Kadın, 2021a

Tablo 6'ya göre her meslek grubunda kadınların erkeklerden düşük oranda var olduğu, kadınların genellikle "kadına uygun "görülen düşük statülü, nitelik gerektirmeyen işlerde yoğunlaştığı izlenmektedir. Kadın mesleği olarak görülmeyen teknisyenlik, tesis ve makine operatörlüğü gibi işlerde kadın oranı oldukça düşük seyretmektedir. Profesyonel meslek mensupları içerisinde kadınlar erkeklere yakın seyir izlemekle birlikte, mesleklerin kendi içinde kadın-erkek dağılımına bakıldığında eşitsizlik yaşandığı görülmektedir. Örneğin profesyonel meslekler arasında yer alan mühendislik alanında TMMOB ${ }^{4 \prime}$ ye bağlı 24 Odanın 2020 y1lı sonu itibariyle toplam 598 bin 437 üyesi olduğu, bu üyelerin cinsiyete göre dağılımına bakıldığında ise 138 bin 960 kadın, 459 bin 477 erkek üye olduğu dikkat çekmektedir. Buna göre mühendisler arasındaki kadın mühendis oranı \%23 tespit edilmektedir (TMMOB, 2021). AÇSHB Türkiye'de Kadın (2021a) raporuna göre Barolara kayıtlı 146 bin 137 avukatın \%46,04'ü, 81 baro başkanının \%10,13'ü kadınlardan

\footnotetext{
${ }^{4}$ Türk Mühendis ve Mimar Odaları Birliği
} 
oluşmaktadır. Tablo 6 fiziksel güç gerektiren işlerde erkek istihdamının yüksek, sosyal ilişki gibi yeterliliklerin gerekli olduğu özellikle hizmet sektöründe bulunan işlerde kadın istihdamının yüksek olduğunu da göstermektedir.

\section{C- Ücret, Ayrımcılık ve Dışlanma İlişkisi Teması}

Kadınların belirli meslek ve işlerde yoğunlaşması ve bu işlerin işgücü piyasasında giderek değer yitirmesi, kadının benzer işlerde erkeklere göre daha az ücret alması da (İleri, 2016) kadınların yaşadığı ayrımcılığa işaret etmektedir. İşlem eşitsizliği olarak karşımıza çıkan ücretlendirmede ayrımcılık, yatay ayrımcılık içerisinde yer almakta ve ücretlerin belirlenmesinde işin içeriğinin değil, işi yapacak kişinin cinsiyetinin esas alınması halini göstermektedir (Erdut, 2006: 4). Ücret farklılıkları, aynı işi yapan kadın ve erkek arasında görülebildiği gibi erkeklerin daha fazla kazanç elde edilen işlerde, kadınların daha düşük ücret getiren işlerde çalıştırılması şeklinde de yaşanabilmektedir. Bu durumda ortaya çıkan gelir eşitsizlikleri, yoksulluğa da sebep olarak firsat eşitsizliğini doğurmaktadır. Zira ücret, kadınların toplumsal yaşamda görünürlüğünü ve birey olarak her alanda eşit olmasını sağlayan temel araçlardan biridir. Ücret gibi ekonomik kaynakların yokluğu/yetersizliği, düşük gelir sorunu, kadınların yaşadıkları eşitsizlikleri derinleştirerek, ayrımcılık, yoksulluk ve tüm boyutlarıyla dışlanma süreçlerine karşı korumasız bırakırken çoğu zaman kadınları sosyal transferlere bağımlı kılmakta ve bu olumsuzluklar gelecek nesillere de aktarılmaktadır. Savunmasızlık ve risklere açık olma durumu özellikle kadının aile reisi olduğu hanelerde yoksulluğun yaygınlaşmasına neden oluşturmaktadır (Erdut, 2006). Genelde yoksullar özelde ise çalışan yoksulların önemli bölümünü oluşturan kadınlar, yoksulluğu çocuklarına aktarmakta, gelirin yetersiz olduğu ailelerde kadın ve çocukların kayıt dışı sektöre yöneldikleri görülmektedir. Bu durum çocukların eğitimden yoksun kalmalarına da neden olarak kısır döngü yaşanmasına sebep olmaktadır.

TÜİK'in en güncel verilerini oluşturan Kazanç Yapısı Araştırmasına (2019) göre, 2018 yılı yıllık ortalama brüt kazancın 49 bin 001 TL olduğu, cinsiyetler açısından değerlendirildiğinde ise kadınlar için bu kazancın 46 bin 208 TL, erkekler içinse 50 bin 297 TL olarak tahmin edildiği görülmektedir. Araştırma, cinsiyete dayalı ücret farkının tüm eğitim düzeylerinde ve toplam düzeyde erkek ücretinin lehine gerçekleştiği sonucuna yer vermektedir. Cinsiyete ve istihdam türüne göre aylık ortalama brüt ücret değerlendirildiğinde, sürekli çalışanlar 4 bin 30 TL aylık ortalama brüt ücret, sürekli çalışan kadınlar 3 bin 809 TL, erkekler ise 4 bin 134 TL aylık ortalama brüt ücret elde etmektedir. Buna göre erkeklerin kadınlara oranla \%8,5 düzeyinde daha fazla gelir elde ettiklerini söylemek mümkündür. Süreksiz çalışanlar açısından değerlendirilme yapıldığında ise kadınların 3 bin 99 TL, erkeklerinse 2 bin 972 TL aylık ortalama brüt ücret elde ettikleri, süreksiz çalışanlarda kadınların \%4,27 daha fazla ücret elde ettiği görülmektedir. Ancak süreksiz çalışan kadınların önemli bölümünün sosyal güvenceden yoksun şekilde kayıt dış1 çalıştığı bilinmektedir. Kadınlar, ağırlıklı olarak tarımda süreksiz çalışmaktadır ve sosyal güvenlik kapsamında isterlerse kendi primlerini ödeme şartıyla sigortalı olma hakkı tanınmaktadır. Ancak bu hak, bilinmemesi ya da kazanç azalır düşüncesiyle yüksek prim oranlarının ödenmek istenmemesi gibi sebeplerle yaygın kullanılmamaktadır. 
Ayrımcılık Temelli Dışlanma: Türkiye’de Çalışma Hayatında Kadınlar

Tablo 7. Eğitim Durumuna Göre Cinsiyete Dayalı Ücret Farkı, 2018

\begin{tabular}{|c|c|c|c|c|}
\hline \multirow[b]{2}{*}{ Toplam } & \multicolumn{3}{|c|}{$\begin{array}{l}\text { Yıllık Ortalama Düzenli Brüt Ücret } \\
\text { (TL) }\end{array}$} & \multirow{2}{*}{$\begin{array}{c}\begin{array}{c}\text { Cinsiyete Dayalı Ücret } \\
\text { Farkı }\end{array} \\
(\%)\end{array}$} \\
\hline & Toplam & Erkek & Kadın & \\
\hline Eğitim Durumu & 46.358 & 47.515 & 43.866 & 7,7 \\
\hline İlkokul ve altı & 33.765 & 35.666 & 28.294 & 20,7 \\
\hline İlköğretim ve Ortaokul & 33.383 & 34.702 & 28.720 & 17,2 \\
\hline Lise & 35.812 & 37.334 & 32.013 & 14,3 \\
\hline Meslek Lisesi & 47.532 & 50.820 & 36.183 & 28,8 \\
\hline Yüksekokul ve üstü & 66.786 & 73.095 & 58.754 & 19,6 \\
\hline
\end{tabular}

Kaynak: TÜİK, Kazanç Yapısı Araştırması, 2019

Erkek ve kadın arasındaki ücret farkının, erkek ücreti içindeki yüzdesi olarak tanımlanan cinsiyete dayalı ücret farkı, saatlik, aylık veya yıllık ortalama düzenli brüt ücret esas alınarak hesaplanabilmektedir (TÜİK, 2019). Tablo 7 'de yıllık ortalama düzenli brüt ücret kullanılarak yapılan hesaplama sonucuna göre cinsiyete dayalı ücret farkının \%7,7 seviyesinde olduğu görülmektedir. Tablo 7'den ayrıca cinsiyete dayalı ücret farkının tüm eğitim düzeylerinde ve toplam düzeyde erkek ücretinin lehine gerçekleştiği gözlenmektedir. Ücret ayrımı en fazla meslek lisesi mezunu kadın ve erkekler arasında gerçekleşirken, en az farkın lise mezunu kadın ve erkekler arasında yaşandığı izlenmektedir.

İşgücü piyasasında yaşanan ayrımcılığın, işlem eşitsizliğinin ücretlere yansıyışını değerlendirebilmek için yıllık ortalama brüt kazançları, eğitim düzeyi ve cinsiyete göre analiz etmek gerekmektedir. Öcal (2021) da istatistiki analizlerin ücret konusunda cinsiyetler arasında farklılıkları göstermediğine değinerek, eğitim seviyesi ve cinsiyet açısından alt ayrıştırmaların yapılmasının, erkek ve kadınlar arasındaki ücret farklarını ortaya koyabilmek için önemli olduğunu vurgulamaktadır.

Tablo 8. Cinsiyet ve Eğitim Durumuna Göre Yıllık Ortalama Brüt Kazanç (TL-2018)

\begin{tabular}{lcccccc}
\hline & $\begin{array}{c}\text { İkokul ve } \\
\text { Altı }\end{array}$ & $\begin{array}{c}\text { İlköğretim ve } \\
\text { Ortaokul }\end{array}$ & Lise & Meslek Lisesi & $\begin{array}{c}\text { Yüksekokul ve } \\
\text { Üstü }\end{array}$ & Toplam \\
\hline Kadın & 29.500 & 30.049 & 33.717 & 38.096 & 62.051 & 46208 \\
\hline Erkek & 37.143 & 36.195 & 39.344 & 54.970 & 78.041 & 50297 \\
\hline
\end{tabular}

Kaynak: TÜIK, Kazanç Yapısı Araştırması, 2019

Tablo 8'de de görüldüğü üzere tüm eğitim düzeylerinde erkeklerin yıllık brüt kazançları kadınlardan yüksek seyretmektedir. Erkekler ilkokul ve altında \%25,9, ilköğretim ve ortaokul düzeyinde $\% 20,45$, lise düzeyinde $\% 16,68$, meslek lisesi düzeyinde $\% 44,29$ ve yüksekokul ve üstü eğitim düzeyinde ise $\% 25,6$ oranında kadınlardan daha fazla kazanç elde etmektedirler. Muzasay (2019) tarafindan gerçekleştirilen çalışmada ise ücret farkları kadınların yoğun olarak istihdam edildiği imalat sektöründe incelenmiş ve ücret farklılığı 
kadınların lehine \%3,9 olarak belirlenmiştir. Ancak çalışmada kadınların, eğitim ve mesleki vasıflarının yüksekliği göz önüne alınınca aslında erkeklerden $\% 6,5$ daha fazla ücret almaları gerektiği ifade edilerek, buna göre hesaplama yapıldığında kadınlar aleyhine \%2,6'lık ücret farklılığı olduğu vurgulanmaktadır. Öcal (2021: 821) da ortalama ücretlerin birbirine yakın olmasının yanılsamaya neden olduğunu, eğitim durumuna göre kadınların işgücüne katılımının heterojen yapı sergilediği ve kayıt dışı, tarım sektörü, küçük ölçekli işletmeler hesaplamalara katılmadığı sürece cinsiyete dayalı ücret farklarının net olarak algılanabilmesinin güçleştiğine dikkat çekmektedir.

Türkiye'de cinsiyetler arası ücret farklılıklarını ortaya koyan araştırma sonuçları, ücretlerde cinsiyete dayalı ayrımcılık yaşandığını ortaya koymaktadır. Buna göre, Çakır (2008) kadın çalışanların ortalama günlük kazançlarının özellikle gıda maddeleri sanayi, hukuk, ticaret ve teknik hizmetler, ecza ve kimyevi madde sanayi, deri ve deriden eşya sanayi, kağıt ve kağıt eşya imali, tütün sanayi gibi sektörlerde erkek işçilerin ortalama günlük kazancının altında kaldığını belirtirken, Dayığlu ve Kasnakoğlu (1997) cinsiyetler arasında hem Türkiye genelinde hem de bölgesel bazda önemli kazanç farklılıkları olduğuna işaret etmektedir. Meslek gruplarını inceleyen çalışmalarda da kadın ve erkeklerin gelirlerinin farklılaştığı (Gürler ve Üçdoğruk, 2007; Duruoğlu, 2007; Aktaş ve Uysal, 2016; Dayığlu ve Başlevent, 2017; Turgut,2019; Aytaç ve Sevüktekin, 2000) izlenmektedir. Bu doğrultuda kanun yapıcı, üst düzey yönetici ve profesyonel mesleklerde çalışan erkeklerin daha fazla kazandığı, aynı sektör ve benzer işleri gerçekleştiren erkeklerin kadınlardan daha fazla ücret aldığı görülmektedir. Kadınların genellikle asgari ücret ve kimi çalışma alanlarında asgari ücretin altında ücret aldıkları, elde ettikleri kazancın erkeklere göre daha eşitsiz biçimde dağıldığı, faaliyet ve faaliyet dışı gelirler açısından kadınların erkeklerin gerisinde kaldığı ve kadınların mali açıdan daha kırılgan oldukları bulgularına ulaşılmaktadır. Ücrete dair çalışmalar sosyal güvenlik kurumuna kayıtlı işgücü üzerinden yapılmaktadır. Ancak kadınların önemli bölümünün kayıt dışı istihdam edilmesi cinsiyetler arası ücret farklılığı ve eşitsizliği hakkında doğru bilgiye ulaşmayı zorlaştırmaktadır (Candır ve İslamoğlu, 2014: 54).

\section{D- Kayıt Dışılık, Ayrımcılık ve Dışlanma İlişkisi Teması}

Düşük ücret, sosyal güvence ve sosyal haklardan yoksunluk bağlamında eşitsizlikleri, dışlanmayı ve kadın yoksulluğunu belirginleştiren istihdamın kayıtlılık durumuna da değinmek gerekmektedir. Kayıt dışılık, kadınların çalışma yaşamını düzenleyen kurumlardan dışlanmasını da kapsamaktadır. Kurumsal dışlanma, çalışma hayatında bulunmasına rağmen kayıt altına alınmama, sosyal güvenlik şemsiyesi altında olmamayı ifade etmektedir. $\mathrm{Bu}$ durum ayrıca eğitim, sağlık gibi alanlarda ihtiyaçların karşılanamamasına, fırsat ve işlem eşitsizliklerine sebep olmaktadır (Çakır, 2008: 36).

Türkiye'de son yıllarda kayıt dışı ekonomiyle mücadelede yol kat edildiği görülse de kadınların kayıt dışı ve enformel sektörde yoğunlaştığı bilinmektedir. Hanenin geçiminden erkeğin sorumlu olduğu düşüncesi ve kadının gelirinin ek gelir olarak algılanması, kadınların işgücü piyasasında daha düşük ücretle çalıştırılma ve işten ayrılmayı daha kolay kabullenmeleri zeminini hazırlamaktadır (Toksöz vd. 2014: 16). Bu durum gerek kadınların kayıt dışı sektördeki talebini artıran gerekse kadınları kayıt dışı işlerde çalışmaya yönelten nedenler arasında yer almaktadır. Öztürk ve Başar (2018) tarafından gerçekleştirilen kadınların kayıt dışı çalışma tercihlerini içeren araştırmada eğitim, yoksulluk, hanehalkı yapısı, medeni durum, hanenin geçiminden sorumlu kişinin kadın olması gibi faktörlerin kayıt dışı çalışmada etkili olduğu bulgusuna ulaşılmaktadır. Türkiye'de kadınların işgücüne katılımı hakkında hazırlanan bir başka raporda da kayıt dışı alanda yoğunlaşmada eş ya da babanın kadının çalışmasına yönelik tutumu, ev dışında güvenlikten şüphe etme, "el alem ne der" zihniyeti ve bakım, ev yükü gibi kültürel sebeplerin etkisine değinilmekte ve zorlaşan 
ekonomik düzende hane geçiminin yalnızca erkeğin kazandığı gelirle sağlanamamasından bahsedilmektedir (DPT ve WB, 2009: 6-23). Kayıtlı istihdamı da kapsaması bakımından kayıt dışı istihdamdan ayrılan enformel sektörün Türkiye'de kayıtlı istihdamı yüksek oranda içerdiğini söylemek mümkün değildir. Evde çalışma/ev eksenli çalışma enformel sektörde yaygın kadın çalışmasını oluşturmaktadır. Toplumsal cinsiyete dayalı ayrımcılık, kadınlar için enformel sektörde çalışmayı kimi zaman tek alternatif haline getirmekte ve istatistiklere tam olarak yansıtılamadığı için ev kadını olarak kabul edilen kadınların önemli bölümünün enformel sektörde istihdamı söz konusu olmaktadır. Ancak güvencesiz, düşük ücretli çalışan bu kadınlar, çalışma hayatı içinde olmalarına rağmen kurumsal dişlanma yaşayarak, toplumsal yaşamdan kopmaktadırlar (Çetinkaya ve Yıldırımalp, 2010: 77; Çakır, 2008: 37).

Tablo 9. Cinsiyete Göre Tarım ve Tarım-Dışı Sektörde Kaylt Dışı İstihdam Oranı (\%)

\begin{tabular}{lccc}
\hline & & Tarım & Tarım Dışı \\
\hline \multirow{2}{*}{ Kadın } & $\mathbf{2 0 1 9}$ & 95,7 & 24,2 \\
\cline { 2 - 4 } & $\mathbf{2 0 2 0}$ & 94,3 & 20,2 \\
\hline \multirow{2}{*}{ Erkek } & $\mathbf{2 0 1 9}$ & 79,5 & 22,4 \\
\cline { 2 - 4 } & $\mathbf{2 0 2 0}$ & 76,2 & 18,9 \\
\hline
\end{tabular}

Kaynak: TÜiK, İstatistiklerle Kadın, 2021a

Tablo 9'da incelendiğinde, kadınların kayıt dışı istihdam oranının erkeklerin oranından özellikle tarım sektöründe yüksek olduğu görülmektedir. Tarım dışı sektörde kadın ve erkeklerin kayıt dışı istihdam oranı arasında çok ciddi fark görülmemekle birlikte kadınların daha yüksek orana sahip olduğu izlenmektedir. Kadınların istihdam ve işsizlik oranları, erkeklerin oranı ile karşılaştırıldığında ortaya çıkan sonucun, kadınların daha çok kayıt dışı istihdam edilmelerinden kaynaklanabileceği ifade edilmektedir. Türkiye'de Kadın Emeği Raporu'nda çalışan her 10 kadından 4'ünün, ücretli çalışan her 10 kadından 2'sinin ve bir milyondan fazla kadının kayıt dışı çalıştırıldığı ifade edilmektedir (DISSK, 2020). TÜİK verileri değerlendirildiğinde herhangi bir sosyal güvenlik kurumuna kaydolmadan çalışan kadın istihdamı yoğun olarak ücretsiz aile işçiliği ve kendi hesabına çalışanlarda görülmektedir. Ücretli, maaşlı veya yevmiyeli çalışan kadınlarda kayıt dışı çalıştırılma oranı düşmektedir.

\section{E- Üst Yönetimde Yer Alma, Ayrımcılık ve Dışlanma İlişkisi Teması}

Kadınların ayrımcı uygulamalarla çalışma hayatında dışlanma yaşadığı bir başka alanı kariyer ve yönetim süreçleri oluşturmaktadır. Dikey ayrımcılık olarak ifade edilen bu durumda da kadınların erkeklerle eşit firsatlara sahip olamadığı görülmektedir. Türkiye'de kariyer aşamasında yasal düzeyde cinsiyetler arasında ayrımcılık bulunmamakla birlikte uygulamada kadınların kariyer yapması/ yükselmesi hususunda yönetim süreçlerinde cinsiyet ayrımcılığının engel oluşturduğu bilinmektedir.

Literatürde kadınların kariyer süreçlerinde yaşadığı engeller cam tavan, cam asansör ve cam uçurum gibi kavramlar ile ifade edilmektedir. Buna göre cam tavan, üst kademelere yükselmede kadınların eğitim, yetenek ve başarılarının dikkate alınmamasını, cinsiyete dayalı gerekçelerden oluşan görünmeyen engellerle önlerinin kesilmesini (Alican ve Sallan Gül, 2008: 60), cam asansör ise erkeklerin kadın işi olarak görülen işlerde bile kadınlara göre 
yükselme olanaklarının daha fazla olmasını, kadınların yönetici olma sürecinde kariyer basamaklarını normal merdiven ile çıkarken erkeklerin cam asansörle hızlı çıkmalarını (Alhas, 2020: 107) ifade etmektedir. Cam uçurum ise işletmelerin kriz içinde ve kötü olduğu durumlarda riskli, başarısız olma ihtimalinin yüksek olduğu işlere üst düzey yönetici olarak kadınların atanması şeklinde tanımlanmaktadır (Yıldız vd., 2016: 511). Bu sorunların aşılmasına yönelik işyerlerinde çeşitli yaklaşımların ileri sürüldüğü ancak yaklaşımların cinsiyet eşitsizliğinin kaynaklarından daha çok, belirtilerine çözüm üretmeye yönelik yüzeysel olduğu ifade edilmektedir (Alican ve Sallan Gül, 2008: 77-89). Çalışma yaşamında yönetim pozisyonlarında erkeklerin çoğunlukta olması ve literatüre giren yeni kavramlar, ayrımcılığın, eşitsizliklerin birer sonucu ve çalışma yaşamı içinde dışlanma olarak karşımıza çıkmaktadır.

TÜİK verileri incelendiğinde yönetici pozisyonlarında, üst ve orta düzey yönetici pozisyonlarında cinsiyetler arasında çok önemli oranda farklılık olduğu görülmektedir. Kadın büyükelçi oranı 2020 yılında \%25, erkek büyükelçi oranı \%75 olarak, yine 2020 yılında toplam 584 milletvekili içerisinde kadın sayısı 101, erkek milletvekili sayısı 483 olarak belirtilmektedir. Buna göre meclise giren kadın milletvekili oranı \%17,3'dür (TÜİK, 2021a).

Tablo 10. Yönetici ve Üst-Orta Düzey Yönetici Pozisyonlarının Cinsiyete Göre Dağılımı (\%)

\begin{tabular}{lccc}
\hline & Yönetici Pozisyonları & $\begin{array}{c}\text { Üst ve Orta Düzey } \\
\text { Yönetici Pozisyonları }\end{array}$ \\
\hline Kadın & $\mathbf{2 0 1 9}$ & 16,2 & 17,5 \\
\cline { 2 - 4 } & $\mathbf{2 0 2 0}$ & 18,2 & 19,3 \\
\hline \multirow{2}{*}{ Erkek } & $\mathbf{2 0 1 9}$ & 83,8 & 82,5 \\
\cline { 2 - 4 } & $\mathbf{2 0 2 0}$ & 81,8 & 80,7 \\
\hline
\end{tabular}

Kaynak: TÜİK, Hanehalkı İşgücü Araştırması, 2019-2020

Çalışma Genel Müdürlüğü verilerine göre 2020 yılı kamu kurum ve kuruluşlarında istihdam edilen personel değerlendirildiğinde, kadınların bürokrasi içerisinde üst düzey karar verici konumlardaki oranının düşük olduğu görülmektedir. Bürokraside üst düzey yöneticilerin \%88,31'i erkek, \%11,69’u kadınlardan oluşmaktadır. Toplam kamu çalışanlarının 2019 yılında \%38,41'ini kadınlar \%61,9'unu erkekler, 2020 yılında ise \%40,33'ünü kadınlar, $\% 59,67$ 'sini erkekler oluşturmaktadır.

Türkiye'de Kadın (AÇSHB, 2021a) raporuna göre İçişleri Bakanlığında görev yapan 1.716 mülki idare amirinden 71'i (\%4,13), HSK 2020 verilerine göre adli ve idari yargida görev yapan toplam 14 bin 909 hâkimden 6 bin 855'i $(\% 45,97)$ ve 6 bin 863 savcıdan 1.016's1 $(\% 14,80)$ kadınlardan oluşmaktadır. 199 üniversitenin 17 'sinde $(\% 8,54)$ kadın rektör görev yapmakta olup kadın dekan oranı ise $\% 18,86$ dır. Tüm bu veriler yüksek eğitimli kadınların nitelikli işlerde çalıştığını, sosyo-ekonomik hayatta aldıkları rollerin arttığını göstermesine rağmen, kariyer süreçlerinde erkekler kadar şanslı olamadıklarını, üst yönetimlere erkekler kadar ulaşamadıklarını da göstermektedir (Parlaktuna, 2010: 1228). 
Ayrımcılık Temelli Dışlanma: Türkiye’de Çalışma Hayatında Kadınlar

Tablo 11. Kamu Kurum ve Kuruluşlarında İstihdam Edilen Personel (2020)

\begin{tabular}{lccc}
\hline Unvanlar & Kadın Çalışan & Toplam Üst Düzey Çalışan & Oran (\%) \\
\hline Vali & 2 & 81 & 2,47 \\
\hline Genel Müdür & 14 & 180 & 7,78 \\
\hline Genel Müdür Yardımcısı & 42 & 330 & 12,73 \\
\hline Başkan & 1 & 38 & 2,63 \\
\hline Başkan Yardımcısı & 10 & 123 & 8,13 \\
\hline Daire Başkanı & 463 & 2.803 & 16,52 \\
\hline Kaymakam & 50 & 1.058 & 4,72 \\
\hline Bölge Müdürü & 9 & 215 & 4,19 \\
\hline Bölge Müdür Yardımcısı & 33 & 506 & 6,52 \\
\hline Toplam Üst Düzey & 624 & 5.334 & 11,69 \\
\hline
\end{tabular}

Kaynak: Aile, Çalışma ve Sosyal Hizmetler Bakanlı̆̆g, 2021

\section{F- Sendikal Örgütlenme, Ayrımcılık ve Dışlanma İlişkisi Teması}

Kadınların çalışma yaşamının önemli kurumlarından biri olan sendikalarda da üyelikörgütlenme ve yönetim-karar mekanizmalarında yer alma olmak üzere iki alanda katılım sorunu bulunmaktadır. Sendikaların tüzüklerinde cinsiyet ayrımı bulunmamasına rağmen kadınlar sendikal demokrasi ve sendika içi temsilde eşitsizlikler yaşamakta, sendikalarda erkek egemenliği devam etmektedir. Son yıllarda konfederasyonlar ve konfederasyonlara bağlı sendikaların bünyesinde kadın örgütlenmelerinin faaliyet gösterdiği izlenmesine rağmen kadın üyelik oranlarının düşük olduğu ve sendikalarda kadınların temsiliyetinin düşük olduğu bilinmektedir. Sendikaların erkek alanı olduğu yönündeki zihniyet, cinsiyetçi dil ve uygulamalar, toplu iş sözleşmesi pazarlıklarının ve sendika toplantılarının uzun, yorucu olması, iş ve aile yükü, kadınların kayıt dışı çalışmaları, örgütlenme ve yönetimde katılımı engelleyen yapısal ve sübjektif nedenleri oluşturmaktadır (Alican ve Sallan Gül, 2008: 70; Urhan, 2014; Yenihan, 2020: 139-144; Ereş ve Öztürk, 2020: 72). Yenihan ve Cerev'in (2016) sendikalı kadınların sorunlarını araştırdıkları çalışmalarının sonucunda sendikalı kadınların aile içerisindeki rolleri, ailevi yükümlülükleri, çalıştıkları kurumların engellemeleri, yönetime katılmada cinsiyet ayrımcılığının varlığı ve sendikaların kadın üyelerinin sorunlarıyla yeterli düzeyde ilgilenmemesi sebebiyle katılım sorunlarını ortaya konmaktadır. Bu engeller bir yandan kadınların sendikalardan uzak kalmasına bir yandan da kadınların sendikal yapılardan dışlanmasına sebep olmaktadır (Çakır, 2008: 41). 
Tablo 12. Cinsiyete Göre İş̧i, Üye Sayısı ve Sendikalaşma Oranı (2019)

\begin{tabular}{llllll}
\hline & & Erkek & Kadın & Bilinmeyen & Toplam \\
\hline İşçi Sayısı & Ocak 2019 & 9.340 .249 & 3.987 .726 & 84.008 & 13.411 .983 \\
\cline { 2 - 5 } & Temmuz 2019 & 9.719 .444 & 3.967 .615 & 77.004 & 13.764 .063 \\
\hline \multirow{2}{*}{ Sendikalı İşçi Sayısı } & Ocak 2019 & 1.447 .940 & 351.718 & 59.380 & 1.859 .038 \\
\cline { 2 - 5 } & Temmuz 2019 & 1.475 .469 & 361.241 & 57.460 & 1.894 .170 \\
\hline \multirow{2}{*}{ Sendikalaşma Oranı } & Ocak 2019 & 15.50 & 8.82 & 70.68 & 13.86 \\
\cline { 2 - 5 } & Temmuz 2019 & 15.18 & 9.10 & 74.62 & 13.76 \\
\hline
\end{tabular}

Kaynak: Aile, Çalışma ve Sosyal Hizmetler Bakanlığı, Çalışma İstatistikleri, 2020

2021 Ocak ayı istatistiklerine göre sendikalaşma oranı \%14,40 olarak gerçeklemiştir. Bu oranın 6356 sayılı Kanun dönemindeki en yüksek sendikalaşma oranı olduğu ifade edilmektedir (AÇSHB, 2021b:8). Çalışma İstatistikleri (AÇSHB,2019) güncel cinsiyete göre hesaplamaları içermektedir. Buna göre Tablo 12 incelendiğinde, sendikalaşma söz konusu olduğunda da toplumsal cinsiyet eşitsizliğinin sürdüğü görülmektedir. Türkiye'deki kadın ve erkek işçi sayısı, sendikalı işçi sayısı ve sendikalaşma oranları, kadın ve erkek arasındaki eşitsizliği belirgin bir şekilde ortaya koymaktadır.

\section{SONUÇ}

Fırsat ve işlem eşitsizliklerine ve dışlanmaya neden olan ayrımcılık, sadece temel insan haklarını ihlal eden bir sorun olarak kalmamakta, çok boyutlu sosyal ve ekonomik sorunlara yol açmaktadır. Bu bağlamda ayrımcılığı sadece hukuki ihlal olarak görerek, ayrımcılık yasağı bağlamında mücadele etmek yeterli kalmamaktadır. Ayrımcılığa maruz kalan grupların başında gelen kadınlar, cinsiyet sebebiyle eşitsiz muamele görmekte ve özellikle kadınları özgür birey kılacak, ikincil konumlarından kurtaracak alan olan çalışma hayatında dışlanma sorunuyla karşılaşmaktadırlar.

Türkiye 2000'li yıllarda başlayan reform sürecinde cinsiyet eşitsizliklerini, ayrımcılığı dolayısıyla dışlanma kaynaklarını önlemeye yönelik yasal düzenlemeler gerçekleştirmesine, cinsiyet eşitsizliklerinin azaltılması konusunda uluslararası indekslerde yıllar içinde ilerleme sergileyen ülkeler arasına girmesine rağmen, uygulamada hala ayrımcılıktan beslenen sorunların varlığı izlenmektedir. Güncel veriler üzerinden Türkiye'de çalışma hayatında kadınların durumu incelendiğinde, kadınların dezavantajlı konumda oldukları açık bir şekilde görülmektedir. Eğitimde firsat eşitsizliğine sebep olan ayrımcılık, kadınların çalışma yaşamına giriş sürecinde dışlanma için belirleyici olurken, çalışma yaşamı içerisinde ücret gibi temel değişkenler açısından ve işlem eşitsizlikleri açısından da önem arz etmektedir. Kadınların eğitim düzeyi arttıkça işgücü piyasasında daha fazla yer aldıkları ancak kadın ve erkeğe toplumun biçtiği roller sebebiyle ev işleriyle meşguliyetin kadınlar için işgücüne dahil olamama nedenlerinin en başında geldiği görülmektedir. Kadınların zaman kullanımları da değerlendirme kapsamına alındığında gerek çalışan gerekse çalışmayan kadınlar için ev işi, çocuk bakımı gibi sorumluluklara harcanan zamanın erkeklere göre fazla olduğu ortaya çıkmaktadır. Veriler, dikey ve yatay ayrımcılık, fırsat ve işlem eşitsizlikleri kıskacında 
Ayrımcılık Temelli Dışlanma: Türkiye’de Çalışma Hayatında Kadınlar

çalışma hayatında var olma mücadelesi veren kadınların “erkek işi”” olarak görülen sektör ve mesleklerden dışlanma, erkeklere göre daha az ücret elde etme, üst yönetim pozisyonlarından dışlanma ve çalışma yaşamının kurumlarından dışlanma gibi belirgin sorunlar yaşadıklarını göstermektedir.

Ayrımcılık ve ayrımcılığın doğurduğu sorunların çözümünde, sadece ayrımcılık yasaklarıyla değil, çok boyutlu yaklaşımla hareket etmek gerekmektedir. Kadınlarının güçlenmesi ve kadınların önüne engel olarak konan zihniyetin ortadan kalkabilmesi için işe eğitimle başlamak gerekmektedir. Sadece kadınları eğitmekle kalmayıp, toplumun eğitim ve bilinç düzeyinin artırılması yolunda adımlar atılmalıdır. Eğitimin ilk kademesinden itibaren, toplumsal cinsiyet eşitsizliklerine sebep olacak önyargılardan, söylemlerden uzak yaklaşımla hareket edilmelidir. Zira kadınlar hane içi engelleri aşsalar da çoğunlukla hane dışı engellerle ayrımcılık yaşayarak, eşitsiz konuma ve dışlanmaya maruz kalmaktadırlar. İş ve aile hayatının uyumlaştırılmasına yönelik politikaların da eşitlikçi olması gerekmektedir. $\mathrm{Bu}$ politikaların toplumsal cinsiyete dayalı ayrımcılık anlayışını besleyecek şekilde sadece kadınların yüklerini hafifletmek, kadınların özel ihtiyaçlarına yönelik olmaktan ziyade eşitliği sağlayacak şekilde geliştirilmesi ve yürütülmesi gerekmektedir. Babalık izni gibi erkekleri de sürece dahil eden düzenlemelerin kadınlar ile eşit şekilde uygulanması, kreş ve bakım hizmetlerinin yaygınlaştırılması çözüme doğrudan katkı sağlayacaktır.

Sonuç olarak kadınların başta çalışma hayatı olmak üzere toplumsal yaşamın her alanına eşit birey olarak katılımının sağlanabilmesi için eşitsizliklere ve dışlanmaya sebep olan ayrımcılıkla mücadelede çok boyutlu ve kısa sürede sonuç verecek eylem planlarının oluşturulması önem arz etmektedir. Türkiye'nin ulusal düzenlemeler ve taraf olduğu sözleşmelerin hükümleri çerçevesinde güvence altına alınan hakların korunması, yaşama geçirilmesi yönünde uygulamaya ilişkin önlemleri alması elzem görülmektedir.

\section{Kaynakça}

Aile, Çalışma ve Sosyal Hizmetler Bakanlığı-AÇSHB (2021a). Türkiye'de Kadın. Ankara. [https://www.aile.gov.tr/media/67948/turkiyede-kadin-20-02-2021.pdf]. (Erişim: 10 Mart 2021).

Aile, Çalışma ve Sosyal Hizmetler Bakanlığı- AÇSHB (2021b). Çalışma Hayatı Gündemi. S. 3. Nisan. [https://www.csgb.gov.tr/media/76148/cgm-aylik-bulten-3-26-04-2021.pdf]. (Erişim: 09 Mayıs 2021).

Aile, Çalışma ve Sosyal Hizmetler Bakanlığı (2020). Çalışma İstatistikleri 2019. Ankara. [https://www.csgb.gov.tr/media/63366/calisma_hayati_2019.pdf]. (Erişim: 12 Mart 2021).

Aksaç Tanay G. ve Akdağ Şenyurt A. (2015). Ayrımcılık ve Engelli Hakları: Engelli Kadınların Hak Temelli Mücadele Adımları Projesi. Engelli Kadın Derneği ve Sabancı Vakfı. 1. Baskı. Mayıs. Ankara.

Akdemir, Ş. D. (2014). Ayrımcılığın İnsan Hakları Boyutu ve 'Pozitif Ayrımcılık'. İnsan ve Toplum Bilimleri Araştırmaları Dergisi. 3(4). 890-908.

Aktaş, A. ve Uysal, G. (2016). The Gender Wage Gap in Turkey. Marmara Üniversitesi İktisadi ve İdari Bilimler Fakültesi Dergisi. 38(2). 1-19.

Alican, A. ve Sallan, Gül, S. (2008). İnsan Hakları Bağlamında Sendikalarda Cam Tavan. İnsan Hakları Y1llığı. Cilt 26. 55-77.

Alhas, F. (2020). Kadınların Üst Düzey Yönetici Olmasına Engel Olan Nedenler: Cam Uçurum, Cam Yürüyen Merdiven ve Cam Asansör Arasındaki İlişkinin İncelenmesi. A ğrl İbrahim Çeçen Üniversitesi Sosyal Bilimler Enstitüsü Dergisi. 6(2). 101-113.

Alparslan, A. M., Çetinkaya Bozkurt, Ö. ve Özgöz A. (2015). İşletmelerde Cinsiyet Ayrımcıllğı ve Kadın Çalışanların Sorunları. Makü İktisadi ve İdari Bilimler Fakültesi Dergisi. 2(3). 66-81. 
Aytaç, S. ve Sevüktekin M. (2000). Çağdaş Sanayi Merkezlerinde Kadın İsgücünün Konumu: Bursa Örneği. TİSK Yayını.

Başlevent, C. ve Onaran, Ö. (2003). Are Married Women in Turkey More Likely to Become Added or Discouraged Workers? Labour. 17(3). 439-458.

Burchardt, T., Le Grand, J. ve Piachaud, D. (2002). Understanding Social Exclusion. Oxford: Oxford University Press.

Candır, H. ve İslamoğlu, E. (2014). Türkiye'de Kadın Çalışanların Sosyal Haklar Açısından Durumu. Bilgi Dergisi. Kış. 29. 39-68.

Çakır, Ö. (2002). Sosyal Dışlanma. Dokuz Eylül Üniversitesi Sosyal Bilimler Enstitüsü Dergisi. 4(3). 83-104.

Çakır, Ö. (2008). Türkiye'de Kadının Çalışma Yaşamından Dışlanması. Erciyes Üniversitesi İktisadi ve İdari Bilimler Fakültesi Dergisi. S. 31. Temmuz-Aralık. 25-47.

Çetinkaya, E. ve Yıldırımalp, S. (2010). Türkiye'de Kadınların Kayıt Dışı İstihdamdaki Durumları. TÜHís İs Hukuku ve İktisat Dergisi. 22(4-5). 75-86

Çitçi, U. S. ve Sağır, P. M. (2017). Potansiyel Erkek Girişimcilerin Perspektifinden Kadın Girişimciliği. Kadin/Woman. 18(1). 41-62.

Çolak, Z. (2021). Türkiye'de Toplumsal Cinsiyet Eşitsizliği-Ekonomik Büyüme İlişkisi Üzerine Ekonometrik Analiz. Manas Sosyal Araştırmalar Dergisi. 10(2). 1094-1105.

Çotuksöken, B. (2010). İnsan Hakları ve Felsefe. İstanbul: Papatya Yayıncılık.

Dayığlu, M. ve Kasnakoğlu, Z. (1997). Kentsel Kesimde Kadın ve Erkeklerin İsgücüne Katılımları ve Kazanç Farklılıkları. ODTÜ Gelişme Dergisi. 24(3). 329-361

Dayığlu, M. ve Başlevent, C. (2017). Türkiye'de Gelir Dağılımının ve Yoksulluğun Toplumsal Cinsiyet Boyutları. Türkiye'de Refah Devleti ve Kadın. (Editörler S. Dedeoğlu ve A.Y. Elveren). İstanbul: İletişim Yayınları. 2.Baskı. 127- 157

Dedeoğlu, S. ve Elveren, A.Y. (2017). Türkiye'de Toplumsal Cinsiyet, Toplum ve Refah Devleti. Türkiye'de Refah Devleti ve Kadın. (Editörler S. Dedeoğlu ve A.Y. Elveren). İstanbul: İletişim Yayınları. 2.Bask1. 29-45

Dedeoğlu, S. (2017). Türkiye'de Refah Devleti, Toplumsal Cinsiyet ve Kadın İstihdamı. Türkiye'de Refah Devleti ve Kadın. (Editörler S. Dedeoğlu ve A.Y. Elveren). İstanbul: İletişim Yayınları. 2.Baskı. 211-229

Dedeoğlu, S. (2010). Visible Hands-Invisible Women: Garment Production in Turkey. Feminist Economics. 16(4). 1-32.

Dedeoğlu, S. (2009). Eşitlik Mi Ayrımcılık Mı? Türkiye'de Sosyal Devlet, Cinsiyet Eşitliği Politikaları ve Kadın İstihdamı. Çalışma ve Toplum. 2009/2. 41-54.

Dedeoğlu, S. (2004). Sinderella'nın Pazara Yolculuğu. Neoliberalizmin Tahribatı Türkiye'de Ekonomi. Toplum ve Cinsiyet. (Haz. Neşecan Balkan, Sungur Savran). Metis Yay. 1. Basım. Mayıs. 254-274

Devlet Planlama Teşkilatı (DPT) ve Dünya Bankası (WB) (2009). Türkiye'de Kadınların İş Gücüne Katılımı: Eğilimler, Belirleyici Faktörler ve Politika Çerçevesi. Beşerî Kalkınma Sektörü Avrupa ve Orta

Asya Bölgesi Rapor No 48508-TR. [https://www.stgm.org.tr/sites/default/files/2020-09/turkiyedekadinlarin-isgucune-katilimi-egilimler-belirleyici-faktorler-ve-politika-cercevesi.pdf]. (Erişim: 29 Nisan 2021)

DİSK/Genel İş̧ Araştırma Dairesi (2020). Türkiye'de Kadın Emeği. [http://cloudsdomain.com/uploads/dosya/21031.pdf]. (Erişim: 02 Mayıs 2021) 
Ayrımcılık Temelli Dışlanma: Türkiye'de Çalışma Hayatında Kadınlar

Duruoğlu, T. (2007). Emek Piyasasında Cinsiyetçi Ücret Ayrımı: Bursa Organize Sanayi Bölgesinde Bir Araştırma. İletişim Kuram ve Araştırma Dergisi. Kış-Bahar. 24. 61-76

Ecevit, Y. (2003). Toplumsal Cinsiyetle Yoksulluk İlişkisi Nasıl Kurulabilir? Bu İlişki Nasıl Çalış1labilir? C. U. Tip Fakültesi Dergisi. 25(4). 83-88

Ecevit, Y. (2007). Türkiye'de Kadın Girişsimciliğine Eleştirel Bir Yaklaşım. Ankara: Uluslararası Çalışma Örgütü (ILO) Yayınları.

Ecevit, F. Y. (2011a). Türkiye'de Kadın Emeği Konulu Çalışmaların Feminist Tarihçesi. Birkaç Arpa Boyu, 21.Yüzyıla Girerken Türkiye'de Feminist Çalışmalar, Prof. Dr. Nermin Abadan Unat'a Armağan. (Derleyen: S. Sancar). İstanbul: Koç Üniversitesi Yayınları. 121-166.

Ecevit, F. Y. (2011b). Kentsel Üretim Sürecinde Kadın Emeğinin Konumu ve Değişen Biçimleri. 1980’ler Türkiye’sinde Kadın Bakış Açısından Kadınlar. (Editör: Şirin Tekeli). 5. Baskı. İstanbul: İletişim Yayınları. 105-114.

Erdoğan, M. ve Vatandaş, C. (2020). Bireysel ve Toplumsal Dışlanma Pratiği: Önyargı ve Ayrımcılık. Insan ve Sosyal Bilimler Dergisi. 3 (1). $474-485$. [https://dergipark.org.tr/en/pub/johass/ issue/54512/724821]. (Erişim: 03 Mart 2021)

Erdoğdu, S. (2004). Sosyal Politikada "Avrupalı” Bir Kavram: Sosyal Dışlanma. Çalışma Ortamı Dergisi. Temmuz-Ağustos. S. 75.

Erdut, T. (2006). İsgücü Piyasasında Ayrımcılık. İkinci Ulusal Sosyal Politika Kongresi. 23-24 Kasım. Türkiye Devrimci İşçi Sendikaları Konfederasyonu ve Friedrich Ebert Vakfı. Ankara.

Ereş, G. ve Öztürk, M. (2020). Kadınların Sendikalarda Görev Almada Karşılaştıkları Sorunlara Yönelik Bir Çalışma. Süleyman Demirel Üniversitesi İktisadi ve İdari Bilimler Fakültesi Dergisi. 25 (1). 71-88.

Erikli, S. (2020). Çalışma Yaşamında Toplumsal Cinsiyet Ayrımcıllğııın Görünümü. Hacettepe Üniversitesi Sosyal Bilimler Dergisi. 2(1). 39-60.

Eyüpoğlu, A., Özar, Ş. ve Tanrı̈̈ver, H. (2000). Kentlerde Kadınların İş Yaşamına Katılmalarının Sosyo-Ekonomik Sorunları. Ankara: KSGM Yayınları.

Göregenli, M. (2012). Önyargıyı ve Ayrımcılı̆̆ı Azaltmak. (Editörler: K. Çayır ve M.A. Ceyhan). Ayrımcıllk: Çok Boyutlu Yaklaşımlar. İstanbul: Bilgi Üniversitesi Yayınları. 247-255.

Gül, İ. I. (2012). Hukukta Ayrımcılık Yasağı. (Editörler: K. Çayır ve M.A. Ceyhan). Ayrımcılık: Çok Boyutlu Yaklaşımlar. İstanbul: İstanbul Bilgi Üniversitesi. 1-18. 190.

Gül, İ. Işıl ve Karan, Ulaş. (2011). Ayrımcılık Yasağı, Kavram, Hukuk, İzleme ve Belgeleme. (Editörler: B. Yeşiladalı ve G. Ayata). İstanbul: İnsan Hakları Hukuku Çalışmaları. Bilgi Üniversitesi Yayınları.

Gülmez, M. (2009). Insan Hakları ve Avrupa Birliği Hukukunda Ayrımcılı̆̆ın Kaldırılması ve Türkiye. Belediye İş Sendikası AB'ye Sosyal Uyum Dizisi. Ankara.

Gürler, Ö. K. ve Üçdoğruk, Ş. (2007). Türkiye'de Cinsiyete Göre Gelir Farklılığının Ayrıştırma Yöntemiyle Uygulanmas1. Journal of Yasar University. 2(6). 571-589.

Hacettepe Üniversitesi Nüfus Etütleri Enstitüsü NEE (2019). Türkiye Nüfus ve Sağlık Araştırması 2018. Ankara. [http://www.hips.hacettepe.edu.tr/tnsa2018/rapor/TNSA2018_ana_Rapor.pdf]. (Erişim: 03 Mart 2021).

İleri, Ü. (2016). Sosyal Politikalarda Kadın ve Cinsiyet Ayrımcılığı ile İlgili Başlıca Uluslararası ve Ulusal Hukuki Düzenlemeler. Hak İş Uluslararası Emek ve Toplum Dergisi. 5(12). 128-153.

İlkkaracan, İ. (2012). Why So Few Women in the Labor Market in Turkey? Feminist Economics. 18(1). $1-37$. 
International Labor Organization- ILO (2009). Decent Equality at the Heart of Decent Work. [https://www.ilo.org/wcmsp5/groups/public/@ed_norm/@relconf/documents/meetingdocument/wcm s_105119.pdf]. (Erişim: 04 Mart 2021).

International Labor Organization- ILO (2008). Youth Employment: Breaking Gender Barriers for Young Women and Men-Gender Equality at the Heart of Decent Work, 2008-2009. [https://www.ilo.org/global/standards/information-resources-and-publications/publications/WCMS_0 97842/lang--en/index.htm]. (Erişim: 04 Mart 2021)

İspir, Z. (2015). Bir İnsan Hakları Sorunu Olarak Cinsiyete Dayalı Ekonomik Ayrımcılık. 5. Uluslararası Kadın ve Toplumsal Cinsiyet Araştırmaları Konferansında Sunulmuş Bildiri.

İnce, M. (2011). The Role of Female Education in Economic Development: A Case For Turkey. Selçuk Üniversitesi Sosyal Bilimler Enstitüsü Dergisi. 26. 227-238.

Kaboğlu, İ. (2002). Özgürlükler Hukuku. Ankara: İmge Yayınevi.

KAGIDER (2019). Türkiye Kadın Girişimcilik Endeksi 2019 Araştırma Raporu. [https://kagider.org/docs/default-source/kagider-raporlar/kagider- $\mathrm{t} \% \mathrm{C} 3 \% \mathrm{BCrk}$-tuborg-kad $\% \mathrm{C} 4 \% \mathrm{~B} 1 \mathrm{n}$ _girisimcilik_endeksi_2019.pdf?sfvrsn=6]. (Erişim: 11 Nisan 2021).

Kandiyoti, D. (1988). Bargaining with Patriachy. Gender and Society. 2(3). 274-90.

Kaya, P. A. (2007). Avrupa Birliği ve Türk İş Hukuku Bağlamında Eşitlik İlkesi. Ankara: Nobel Yayın.

Korkut, L. (2009). Ayrımcılık Karşıtı Hukuk. İnsan Hakları Gündemi Derneği. Ankara.

Memiş, E., Öneş, U. ve Kızılırmak, B. (2017). Kadınların Ev-Kadınlaştırılması: Ücretli ve Karşılıksız Emeğin Toplumsal Cinsiyet Temelli Bir Analizi. Türkiye'de Refah Devleti ve Kadın. (Derleyen: S. Dedeoğlu ve A.Y. Elveren). İstanbul: İletişim Yayınları. 2.Baskı. 159-182.

Metin, Ş. ve Kariman, R. A. (2013). TBMM Kadın Erkek Fırsat Eşitliği Komisyon Raporu 2014. TBMM Kadın Erkek Fırsat Eşitliği Komisyonu Yayınları No: 12. http://www.tbmm.gov.tr/komisyon/kefe/docs/komisyon_raporu_2014_1.pdf). (Erişim: 11 Şubat 2021).

Musazay, Sarah (2019). Gender Wage Gap and International Trade: Evidence From Turkey's Manufacturing Sector. İbni Haldun Üniversitesi. Lisansüstü Eğitim Enstitüsü. (Yayımlanmamış Yüksek Lisans Tezi). Ağustos.

Öcal, T. A. (2021). Türkiye'de İşgücü Piyasasında Toplumsal Cinsiyet Eşitsizliği. World Women Conference-II February 11-12. Baku. Azerbaijan. 813-825.

Önder, N. (2013). Türkiye'de Kadın İşgücünün Görünümü. ÇSGB Çalışma Dünyası Dergisi. 1(1) Temmuz-Eylül. 35-61.

Öztürk, S. ve Başar, D. (2018). Türkiye'de Kadınların İşgücü Piyasasına Yönelik Tercihleri: Kayıt Dışı Sektör Özelinde Bir Analiz. Sosyal Güvenlik Dergisi (Journal of Social Security). 8(2). 41-58

Parlaktuna, İ. (2010). Türkiye'de Cinsiyete Dayalı Mesleki Ayrımcılık. Ege Akademik Bakış. 10(4). 1217-1230.

Sallan-Gül, S. ve Altındal, Y. (2016). Türkiye'de Kadın Girişimciliğin Serüveni: Başarı Mümkün Mü? Süleyman Demirel Üniversitesi İ̈BF Dergisi. 21(4). 1361-1377.

Sapancalı, F. (2005). Avrupa Birliği’nde Sosyal Dışlanma Sorunu ve Mücadele Yöntemleri. Çalışma ve Toplum. 2005/3. 51-106.

Seçkin-Halaç, D. ve Meşe G. (2021). Toplumsal Cinsiyet Bakış Açısından Türkiye'de Kadın Girişimciliğinin Durumu. Dumlupınar Üniversitesi Sosyal Bilimler Dergisi. 68. 255-270.

Seçkin-Halaç, D. ve Seçkin-Çelik, T. (2018). A Qualitative Look Into Gendered Entrepreneurship in Turkey. İstanbul Business Research. 47(2). 105-123. 
Ayrımcılık Temelli Dışlanma: Türkiye'de Çalışma Hayatında Kadınlar

Serel, H. ve Özdemir, B. S. (2017). Türkiye'de Kadın İstihdamı ve Ekonomik Büyüme İlişkisi. Yönetim ve Ekonomi Araştırmaları Dergisi. 15(3). 132-148.

Şahin, M. (2017). Türkiye'de Sosyal Güvenlik Reformu ve Kadınlar Üzerine Etkisi. Türkiye'de Refah Devleti ve Kadın (Derleyen: S. Dedeoğlu ve A.Y. Elveren). İstanbul: İletişim Yayınları. 2.Baskı. 231277.

Taşğın Ş. N. (2021). Irkçılık ve Ayrımcılı̆̆ın Önlenmesi: Türkiye'deki Mevcut Durum ve Sosyal Hizmet İçin Öneriler. Toplum ve Sosyal Hizmet. 32(1). Ocak. 293-315.

Tokol, A. (2013). Ayrımcılık ve Sosyal Dışlanma. Sosyal Politika II (Editörler: Doç. Dr. Abdurrahman İlhan Oral ve Dr. Öğr. Üyesi Yener Şişman). Eskişehir: Anadolu Üniversitesi Yayınları.

Toksöz, G. Dedeoğlu, S. Memiş Parmaksız, E. ve Kaya Bahçe, S. (2014). Türkiye'de Kadın İşgücü Profili ve Istatistiklerinin Analizi. Aile ve Sosyal Politikalar Bakanlığı Kadının Statüsü Genel Müdürlüğü.

Toksöz, G. (2017). Neoliberal Piyasa, Özel ve Kamusal Patriarka Çıkmazında Kadın Emeği. Türkiye'de Refah Devleti ve Kadın. (Derleyen: S. Dedeoğlu ve A.Y. Elveren). İstanbul: İletişim Yayınları. 2.Baskı. 103-126.

Tunç, M. (2018). Kalkınmada Kadın Ayrımcılığı ve Toplumsal Cinsiyet Eşitsizliğinin Rolü: Ülkelerarası Farklı Gelir Gruplarına Göre Yatay Kesit Analiz. Sosyoekonomi. 26(28). 221-251.

Turgut, Ş. A. (2019). Türkiye'deki Gelir Eşitsizliğinin Toplumsal Cinsiyet, Kadının İstihdamı ve Kadın Yoksulluğu Açısından Değerlendirilmesi. Kocaeli Üniversitesi Sosyal Bilimler Dergisi. 38. 315- 329.

T.C. Aile, Çalışma ve Sosyal Hizmetler Bakanlığı Aile ve Toplum Hizmetleri Genel Müdürlüğü (2019a). Türkiye Aile Yapısı Araştırması - TAYA 2016. Birinci Basım. Ankara: TDV Yayın.

T.C. Aile, Çalışma ve Sosyal Hizmetler Bakanlığı Aile ve Toplum Hizmetleri Genel Müdürlüğü (2019b). Türkiye Aile Yapısı İleri İstatistik Analizi-TAYA 2018. Birinci Basım. Ankara: TDV Yayın.

TÜiK (2015). Zaman Kullanım Araştırması 2014-2015. [https://tuikweb.tuik.gov.tr/ PreTablo.do?alt_id=1009]. (Erişim: 21 Şubat 2021).

TÜIK (2017). Aile Yapısı Araştırması. [https://tuikweb.tuik.gov.tr/PreHaberBultenleri.do?id=21869]. (Erişim: 09 Nisan 2021).

TÜIK (2019). Kazanç Yapısı Araştırması. [https://tuikweb.tuik.gov.tr/PreHaberBultenleri.do?id=30580]. (Erişim: 12 Nisan 2021).

TÜIK (2020). Girişimcilik 2016-2018. [https://tuikweb.tuik.gov.tr/PreHaberBultenleri.do?id=33664]. (Erişim: 08 Nisan 2021).

TÜIK (2021a). İstatistiklerle Kadın 2020. [https://tuikweb.tuik.gov.tr/PreHaberBultenleri.do?id=37221]. (Erişim: 20 Mart 2021).

TÜIK (2021b). İşgücü İstatistikleri 2020. [https://data.tuik.gov.tr/Bulten/Index?p=Isgucu-Istatistikleri2020-37484]. (Erişim: 20 Nisan 2021).

TMMOB (2021). “TMMOB'a Bağlı Odaların Üye Sayısı-2020”. [http://www.tmmob.org.tr/icerik/tmmobye-bagli-odalarin-uye-sayisi-590-bin-oldu\#: :text=TMMOB'ye $\% 20 \mathrm{ba} \% \mathrm{C} 4 \%-9 \mathrm{Fl} \% \mathrm{C} 4 \% \mathrm{~B} 1 \%$ 2024\%20Odan\%C4\%B1n,18\%20bin\%20569\%20ki\%C5\%9Fi\%20artt\%C4\%B1]. (Erişim: 01 Mart 2021).

URHAN, B. (2014). Sendikasız Kadınlar Kadınsız Sendikalar -Sendika Kadın İlişkisinde Görülen Sorun Alanlarını Belirlemeye Yönelik Bir Araştırma. 1. Baskı. İstanbul: Kadav Yayınları.

Uyar, L. (2006). Birleşmiş Milletler'de İnsan Hakları Yorumları: Insan Hakları Komitesi ve Ekonomik, Sosyal ve Kültürel Haklar Komitesi 1981-2006. İstanbul Bilgi Üniversitesi Yayınları. 
Yenihan. B. (2020). Çalışma Yaşamında Kadının Sendikal Örgütlenmesi ve Karşılaşılan Sorunlar. Kadının Çalışma Hayatındaki Örgütlenme Mücadelesi. (Editörler: G. Cerev ve Bahattin Gökhan Topal). 1.Bask1. Bursa: DORA Basım-Yayın.

Yenihan, B. ve Cerev, G. (2016). Sendikalı Kadınlar ve Yaşadıkları Sorunlar: Kocaeli-Gölcük'de Kamu Çalışanları Sendikaları Üzerine Nitel Bir Araştırma. Yönetim ve Ekonomi Araştırmaları Dergisi. 14(4). $150-167$.

Yıldırım, M. (2014). Ayrımcılık. Sosyal Politika. (Editörler: A. Tokol ve Y. Alper) Bursa: Dora Yayınevi. 283-303.

Yıldız, S., Alhas, F., Sakal, Ö. ve Yıldız, H. (2016). Cam Uçurum: Kadın Yöneticiler Cam Tavanı Ne Zaman Aşar? Ankara Üniversitesi SBF Dergisi. 71(4). 1119-1146. 